\title{
Personal and Corporate Saving in South Africa.*
}

\author{
JANINE ARON \\ Centre for the Study of African Economies, \\ Department of Economics and Statistics, \\ University of Oxford, England \\ AND \\ JOHN MUELLBAUER \\ Nuffield College, University of Oxford, England
}

1 July, 2000

\begin{abstract}
Low domestic savings rates in South Africa run the risk of perpetuating a low growth trap. The decline in government saving, a major reason for the overall decline, is now being reversed. However, personal sector saving rates have fallen since 1993, and corporate rates since 1995, and both may decline further with lower real interest rates. It is important to understand their behaviour in order to formulate policy to raise the domestic saving rate in line with growth needs. This paper summarises our work on the household sector, emphasising the role of financial liberalisation, assets and income expectations, and it explains sectoral linkages and policy implications. Further, the paper analyses the corporate saving rate in detail. Models are developed both for the share of profits in national income, including roles for the terms of trade, tax effects and the price/unit labour cost margin; and for the share of corporate saving in profits, which we find depends on inflation, the real interest rate, dividend taxation and financial liberalisation. This area is remarkably under-researched, given the importance of corporate saving in many economies, and our research thus puts the saving and growth concerns of Kaldor into a modern empirical context.
\end{abstract}

\footnotetext{
* Earlier versions of this paper were given at the Econometric Society European Meeting, Berlin, 29 August-2 September, 1998, and the conference "Saving in the World: Puzzles and Policies", 16-18 September, 1998, The World Bank. We are grateful for comments and advice from Christopher Adam, Gavin Cameron, Alan Gelb, Brian Kantor, Jonathan Leape, Cathy Pattillo, Jim Poterba, Klaus Schmidt-Hebbel, Luis Serven, Francis Teal, Lynne Thomas, Peter Worthington, and two anonymous referees to this journal. We acknowledge funding support from the Southern African Department of The World Bank; and the Economic and Social Research Council, U. K. (award number H52427003594 and grant number R000237500). Assistance from the South African Reserve Bank is gratefully acknowledged, particularly from Danie Meyer, Johan Prinsloo, Herman Smith and Johan Van den Heever.
} 
Low domestic saving rates in South Africa have serious implications for the achievement of investment-driven growth in the medium-term. Gross domestic saving to gross national disposable income has fallen sharply from the early 1980s to the late 1990s, from an average of 24 percent in 1982-89 to 14 percent in 1998; while the net saving ratio (after depreciation) fell from 8 percent to 1 percent (see Figure 1). These low rates of gross saving compare poorly with comparable emerging market economies such as Chile. Low and falling saving rates imply increasing reliance on foreign capital inflows. Yet, the sustainability of higher medium-term capital inflows is uncertain, given recent currency crises and the increased risk premia for emerging markets more generally. Unsurprisingly, real interest rates have been very high in the 1990s, particularly after the currency crises of 1996-98, when real growth fell sharply (see Figure 2). The implications of low saving are even more far-reaching when considering spillover effects from South African growth to impoverished neighbouring economies.

Over the longer term in South Africa the decline in the domestic saving rate has been mainly influenced by the falling government saving rate from the early 1980s (Figure 1). The private saving rate has been more stable, except for the late 1970s when gold prices rose, and a period of very high gold prices in 1979-80, when large windfall profits were retained by the mining industry. Figure 3 reveals that increased corporate saving has sustained the level of private saving in the face of a decline in household saving, particularly in the 1980s. Saving by the personal sector exceeded that by the corporate sector until the mid-1970s, when there was a strong rise in corporate saving, almost doubling its ratio to national income by 1980-85, and remaining high even after the 1979-80 gold price boom. While government dissaving peaked in 1993, the improved saving performance, particularly creditable in the context of weak recent growth rates, has been offset by a fall in private saving. Figure 3 shows this fall to have been driven by the decline in personal (or household) saving, associated with a rapid rise in credit-financed consumer spending, while corporate saving has also weakened since 1995 .

There is little published literature on saving behaviour in South Africa, surprising given the importance of household consumption and corporate investment in GDP and their role in the monetary policy transmission mechanism from interest rate changes to output. Private saving has been analysed by Prinsloo (1994, 1997), Barr and Kantor (1994) and Tsikata (1998). These authors hypothesise that the offsetting patterns of personal and corporate saving referred to above had much to do with households "piercing the corporate veil". For an early discussion of "piercing 
the veil', or in their terms, 'ultrarationality' of households, see David and Scadding (1974). The implication is that households rationally reduced their saving to reflect the fact that when saving by corporations increased in response to changed inflation and tax rates (with correspondingly reduced dividend payments), this raised the value of equities held directly by households or by pension funds on their behalf. If the rise in corporate saving was completely offset by the fall in household saving, due only to "piercing the veil", therefore, the compositional change in private saving would be of little policy consequence. Indeed the above authors suggest that policies towards improving national saving should be focused firmly on raising the government's saving rate, rather than the rate of private saving.

However, there are several reasons why the compositional change in private saving may not be innocuous, and why the stability of private saving may be in doubt. First, several papers give evidence suggesting that the "piercing of the veil" is incomplete. If households see through corporate budget constraints perfectly, dividend income should have no direct effect in a consumption model after incorporating the equity wealth effect. Poterba (1991) finds evidence for the U.K., U.S. and Canada that the effect is not zero. Second, even if households did "pierce the veil", there is no guarantee that corporations would then behave in the way households desired. For example, a number of papers explain the apparently large issue of dividends in the U.K. and U.S., despite unfavourable individual tax treatment, by corporate signalling or reputational devices (Bond et al, 1995; Poterba, 1987).

Third, there could be several other causes of changing relative sectoral saving ratios, with differing degrees of offset, and hence implications for the overall private saving rate. One long-term factor implying some offset between the two sectors' saving rates is financial liberalisation, which has allowed South African households to raise debt to income ratios very strongly since the early 1980 s. Since household debt has its counterpart in corporate assets, particularly of financial corporations, this might help to account for the relatively high corporate saving rate sustained into the 1990s. Similarly, an incomplete offset could result from the response of the two sectors to changing terms of trade or to a shift in government saving behaviour. Still other factors, such as lower real interest rates, might change corporate and household saving in the same direction.

Far from being irrelevant to the question of raising national saving, therefore, the changing composition of private saving could have multiple causes and merit specific policy responses. This requires a rigorous empirical examination of the factors driving each of household and corporate 
saving. In this paper, we explore the determinants of private saving in South Africa, separately examining personal and corporate sector saving behaviour over nearly three decades, from the late 1960s to 1997. In each case, we subject the "corporate veil" hypothesis to more rigorous empirical testing than hitherto.

The observed decline in personal saving in South Africa is examined drawing on Aron and Muellbauer (2000a), which estimates a quarterly solved-out consumption function for South African households. Prior to this study, the most comprehensive consumption function was from the South African Reserve Bank model, separately modelling four components of consumption, durables, semi-durables, non-durables and services (Pretorius and Knox, 1995). However, this model excluded relative prices, assets and debt, proxies for expectations and measures of financial liberalisation. These are important omissions. Fluctuations in asset prices and changes in financial liberalisation can lead to huge forecasting errors when these variables are absent (as in the U.K. in the 1980s, see Muellbauer and Murphy, 1995). The omission of asset stock variables is not surprising, since the South African Reserve Bank does not construct these measures. However, this also made it impossible to test rigorously whether households "pierce the corporate veil".

The models in Aron and Muellbauer (2000a) have remedied some of these problems. Income forecasts were generated from a separate income forecasting model; an innovative indicator for financial liberalisation was derived, which was closely linked to institutional changes; and finally, wealth estimates were constructed, given the absence of official data on wealth estimates (details in Muellbauer and Aron, 1999).

The general issue of corporate saving is highly under-researched, and not only in developing countries, receiving less than one page in the comprehensive survey of Deaton (1999). The area lacks a generally agreed theory of corporate finance to parallel the intertemporal models of households. Two of the very few empirical analyses of aggregate corporate retention rates are by Poterba $(1987,1991)$. Our analysis extends his treatment by articulating several of the underlying economic mechanisms. Moreover, because the corporate profit share of national income can be quite variable, unlike Poterba, we model the profit share separately in order to derive corporate saving as a share of national income. We therefore incorporate one of the neglected key insights of Kaldor's growth model (Kaldor, 1957). This argues that since the propensity to save out of corporate profits is higher than out of labour income, the private sector saving rate out of national 
income depends on the share of profits. However, unlike Kaldor, we endogenise the sectoral saving propensities and address the inter-sectoral linkages.

There is a large literature on the effects of financial deregulation on saving, investment and growth, see the survey by Fry (1995), ch.8. Our analysis of the overall effects on private saving in South Africa of financial liberalisation contributes to this literature, though it should be noted that South Africa has long had a sophisticated financial system and has never experienced financial repression on the scale seen in many less developed countries.

Finally, our research throws light on the monetary transmission mechanism in South Africa, highlighting some of the policy dilemmas faced by the South African Reserve Bank.

\section{Data issues and regime shifts}

South Africa is a dualistic economy, with a highly unequal income distribution. With an incomebased Gini coefficient of 0.61, calculated using 1993 household survey data, South Africa lies second in inequality only to Brazil amongst middle income countries (Klasen, 1997). Gini measures of the inequality of earnings of urban employed men are about 0.5 for both 1980 and 1993, suggesting little decline in inequality, though racial discrimination has fallen (Moll, 1998).

With such an unequal income and expenditure distribution ${ }^{1}$, the bulk of aggregate saving will be accounted for by the most affluent households. Aggregate behaviour as modelled in this paper thus focuses on the formal part of the economy, which has the dominant economic weight. This neglects welfare issues connected with the saving of poorer households, important in its own right, but which the national aggregates cannot address ${ }^{2}$.

For historical reasons, South Africa has a large urban unemployed class, by contrast with many countries in sub-Saharan Africa. Recent research based on different measures of unemployment in South Africa suggests, on a broad definition of unemployment, a range from 30-40

percent (Kingdon and Knight, 1999). Clearly it is difficult to measure the unemployment rate in a

$1 \quad$ Based on a comprehensive socio-economic survey in 1993, the top 30 percent of households in South Africa, accounting for 21 percent of the population, accounted for 75 percent of the expenditure (World Bank research quoted in RDP (1995)).

2 Note that in data revisions in the early 1990s, the South Africa Reserve Bank attempted to incorporate more of the informal sector and service economy into GDP data. Recent revisions from June 1999 (after the period modelled in this paper) continued this process. 
meaningful sense. High unemployment, frequently used as a measure of income uncertainty in countries with lower unemployment, is unlikely to have much of an influence on saving behaviour in the formal part of the economy and hence on aggregate saving behaviour in South Africa (controlling for income, interest rates and other variables). In South Africa's highly segmented labour market, it makes sense instead to proxy income uncertainty with formal sector indicators of labour market tightness, such as capacity utilisation.

The South African economy has been subject to many political shocks and discontinuities, as well as terms of trade shocks. International trade and financial sanctions, foreign disinvestment, capital flight and emigration in the "Apartheid" era, and (to some extent at least) their subsequent reversal during the 1990s, have had large implications for macroeconomic outcomes and policy. There have also been important domestic regime changes, notably in exchange rate and monetary policy, and in regulation.

Such shifts have required creative modelling of regime breaks. For instance, we employ stochastic trends in income expectations models, which help to capture changes in income growth trends linked to political effects. Further, using detailed institutional changes, we constructed indicators for crucial monetary policy regime shifts in the 1980s; and for financial liberalisation in the 1980s and 1990s. The former plays an important role in our income forecasting models in capturing shifts in the influence of interest rates. Financial liberalisation has important effects in our household and corporate saving models. It should be noted that South Africa's financial sector is highly sophisticated, far more than in other sub-Saharan African economies, and financial liberalisation again mainly affects formal sector savers. The real interest rate was largely positive during 19601998 (see Figure 2), and the main consequence of financial liberalisation has been easier credit and more easily collateralised and so more spendable illiquid assets.

With incomplete or less than comprehensive data, where possible, we constructed data; but in some instances, limited data constrained the possible analysis. For instance, in the absence of published data on stocks of personal assets (available in considerable part only on a flow basis, and often at book rather than market value), we constructed the first-ever series for a range of personal assets at market value (see Muellbauer and Aron, 1999, and also Figure 5). These wealth effects prove very important in personal saving. However, we were unable to construct asset series for unincorporated businesses and directly-held foreign assets. Our efforts to capture income distributional effects using ratios of black to white formal sector wages failed, perhaps due to 
weaknesses of these data, especially in the 1990s. Time series of data on the age-distribution are not available, though it would have been useful to test for demographic effects by age of formal sector savers. Similarly, the international migration figures are poor: yet, to the extent that recent emigrants have been among the higher savers, their emigration may have helped to reduce the saving ratio.

\section{Modelling personal saving}

The approach adopted is to split the ratio of personal saving ${ }^{3}$ to national income into two ratios: the ratio of personal saving $(\mathrm{S})$ to personal disposable income $(\mathrm{PDI})$, and the ratio of the latter to gross national disposable income (GNDI). Thus,

$$
\mathrm{S} / \mathrm{GNDI}=\mathrm{s} .(\mathrm{PDI} / \mathrm{GNDI})
$$

where $\mathrm{s}$ is the personal sector saving ratio S/PDI.

Figure 4 illustrates all three ratios. The share of PDI in GNDI is clearly inversely correlated with the share of profits, see Figure 8, given the large labour income element in PDI. We do not model this ratio formally, but it depends also on personal sector tax rates, transfer income to the personal sector from government, and self-employment and property income of the personal sector.

The saving ratio, s can now be linked to the consumption function. Since s is a small number, the approximation holds that

$$
\mathrm{s} \approx-\log (1-\mathrm{s})=-\log (\mathrm{C} / \mathrm{PDI})
$$

where $\mathrm{C}$ is consumer expenditure in current prices. The models we discuss for the log of consumption below can therefore be translated easily into models for the ratio of personal saving to gross national disposable income. 


\subsection{Theoretical issues}

The canonical rational expectations permanent income hypothesis, as derived by Hall (1978) has both an 'Euler' and a 'solved out' representation. Under a number of simplifying assumptions ${ }^{4}$, Hall derived a martingale property for the intertemporal efficiency condition on consumption, or the Euler equation:

$$
c_{t}=c_{t-1}+\varepsilon_{t}
$$

where $c_{t}$ is consumption measured in constant prices and $\varepsilon_{t}$ is a stochastic variable, unpredictable from information dated $\mathrm{t}-1$, which captures news about permanent income. Note that equation (2.3) embodies the extreme consumption smoothing implication of the rational expectations permanent income hypothesis (REPIH), since at $t-1$, the consumer plans future consumption levels to be the same as the current level.

Solving this efficiency condition and its equivalents for all future periods gives the solved-out form of the consumption function

$$
c_{t}=r A_{t-1}+E_{t y} p_{t}
$$

where $\mathrm{y}_{\mathrm{t}}$ is permanent non-property income (consisting of post-tax employment income and transfers from government $)^{5}, r$ is the real rate of return, and $A_{t-1}$ is the real asset stock at the end of the previous period.

3 Personal saving in the National Accounts is conventionally defined as personal disposable income minus consumer expenditure. The latter includes expenditure on consumer durables, but not on the acquisition of owner-occupied housing, which is treated as part of saving.

$4 \quad$ These include the absence of credit restrictions; quadratic utility and certainty equivalence; rational expectations; intertemporally additive preferences implying the absence of habits; a constant real interest rate equal to the rate of subjective time preference; and behaviour equivalent to that of an infinitely-lived household. Much research since Hall (1978) has been concerned with relaxing such assumptions.

5 Non-property income is the theoretically relevant measure and excludes interest income, rents, and returns on equities and stocks. 
To make the solved-out form empirically useful requires at least one more equation, namely an income forecasting model, which relates permanent non-property income to observable variables. There are a number of advantages of the solved-out model, compared to the more fashionable Euler equation. First, it is directly relevant for policy analysis, for instance, to analyse the effects of a tax reform (via the income forecasting model), which could alter the profile of future household income.

Secondly, the solved-out consumption function does not throw away important long-run information in the consumption, income and assets data - on this see the cointegration literature (e.g. Davidson et al, 1978, Engle and Granger, 1987, and Banerjee et al (1993). In the Euler approach, the asset data are not used, while by differencing, consumption and income, which are typically nonstationary, are reduced to stationarity.

Thirdly, while the solved-out approach is clearly more demanding in information and modelling effort, the approximations needed to obtain policy-relevant consumption functions of the type described in the next section are no more extreme than those popularly made in the Euler equation context, by, for example, Hall and Mishkin (1982), Campbell and Mankiw (1989, 1991), and many others, to incorporate credit constraints or myopia.

\subsection{Empirical methodology: derivation of a basic solved-out consumption function}

We set out an empirical methodology for estimating the consumption function, drawing on the theoretical approach of the literature but, importantly, introducing income forecasts, estimates of wealth - distinguishing between liquid and illiquid assets, and an indicator of financial liberalisation (for more detail see Aron and Muellbauer, 2000a).

At the micro-level, a solved-out consumption function is the solution to an intertemporal utility maximizing problem, the classic case being the canonical REPIH in equation (2.4). A loglinearisation of (2.4) makes $\log (\mathrm{c} / \mathrm{y})$ a linear function of the asset-to-income ratio $\mathrm{A} / \mathrm{y}$, and of $\log$ $\mathrm{y}^{\mathrm{p}} / \mathrm{y}$, where the latter can be proxied by forecasts of the income growth rate. Introducing habits or adjustment costs implies a partial adjustment model.

Extending the model from point to probabilistic income expectations, introduces a measure of income uncertainty, $\theta_{\mathrm{t}}$, as well as expected income growth, measured by $\mathrm{E}_{\mathrm{t}} \Delta \log _{\mathrm{g}}^{\mathrm{ma}}{ }_{\mathrm{t}+1}$, defined as a weighted average of forward-looking growth rates. Further, if real interest rates are variable, theory suggests the real interest rate $r_{t}$ enters the model. Incorporating these three additional 
variables, a simple linearization gives the following generalisation of the canonical REPIH model of equation (2.4):

$$
\begin{aligned}
\Delta \log _{\mathrm{t}} & \approx \beta\left[\alpha_{0}-\alpha_{1} \mathrm{r}_{\mathrm{t}}-\alpha_{2} \theta_{\mathrm{t}}+\log \mathrm{yt}_{\mathrm{t}}+\alpha_{3} \mathrm{E}_{\mathrm{t}} \Delta \log _{\mathrm{t}}{ }_{\mathrm{t}+1}^{\mathrm{a}}+\gamma \mathrm{A}_{\mathrm{t}-1} / \mathrm{y}_{\mathrm{t}}\right. \\
& \left.-\log \mathrm{c}_{\mathrm{t}-1}\right]+\varepsilon_{\mathrm{t}}
\end{aligned}
$$

where $\beta$ measures the speed of adjustment. Making the same assumptions as Campbell and Mankiw $(1989,1991)$ to incorporate credit-constrained behaviour by households can be shown to result in an equation for aggregate consumption which is a generalisation of equation (2.5), containing an additional income growth term, $\Delta \operatorname{logyt}$.

While consumption theory puts great weight on income expectations, explicit empirical models for the income process are rare in consumption modelling. The Lucas critique (Lucas, 1976, 1981) argues that conventional reduced form econometric models break down when policy rules change since agents' expectations-generating functions alter. He concludes that the models are of little use for policy analysis. One solution is to address the critique directly, by building an income forecasting model that recognises the importance of policy feed-back rules and is sensitive to possible shifts in these rules.

The aggregation of assets into a single quantity, A, in equation (2.5) is oversimplified. We argue that wealth effects differ according to the liquidity characteristics of different types of wealth. Households usually hold a balance of assets, liquid assets, which can easily be converted into expenditure when needed, and illiquid assets, that typically yield higher rates of return. This suggests making allowance in empirical work for degrees of liquidity by associating different spendability weights with different types of assets and debt. ${ }^{6}$

Housing $^{7}$, pension funds and life insurance funds are at the illiquid end of the spectrum. A delayed impact on consumption is likely from pension wealth. Contractual saving contribution rates

6 Some previous studies have allowed different weights on liquid and illiquid assets, e.g. Patterson (1984); while a number have included liquid asset effects alone, e.g. Zellner, Huang and Chau (1965) and Hendry and von Ungern Sternberg (1981).

7 Note that housing wealth is a special case because housing has consumption as well as wealth purposes (housing services also appear in the utility function): thus, an increase in real house prices has both an income and substitution effect on consumption, partly offsetting the 
often respond with considerable lags to changes in the asset values of such pension funds, suggesting testing for longer lags on consumption.

There is another factor, financial liberalisation, which theoretically both has consequences for the liquidity characteristics of different assets, and which directly and indirectly might be expected to affect consumption. While the implications of financial liberalisation have aroused interest and controversy, and a growing literature (e.g. Bayoumi, 1993a, 1993b; Schmidt-Hebbel and Serven, 1997; Bandieri et al, 1998; Honohan,1999), there has not previously been an entirely satisfactory treatment in applied work on consumption. The difficulty has been to find an indicator of credit market deregulation to drive the various direct and interaction effects of financial liberalisation. These are as follows. First, financial deregulation is likely to raise the propensity to spend directly by reducing the required deposit needed to buy a house, see Japelli and Pagano (1994) and discussion in Deaton (1999), p. 53-54. Second, financial deregulation is likely to increase the spendability weights on illiquid assets since housing collateral and to a lesser extent pension collateral could be used for borrowing and hence for spending. Third, financial liberalisation should reduce the proportion of credit-constrained households. With the increase in credit-unconstrained households, there is a greater role for the real interest rate and expected real income growth on aggregate consumption. However, the effect of uncertainty on consumption may weaken if consumers anticipate that they can more easily borrow in the event of negative income shocks. Finally, there may be an interaction between financial liberalisation and income distribution, as access to credit is extended at lower income levels.

\subsection{Key findings}

\section{(i) Income expectations}

In Aron and Muellbauer (2000a), forecasts of personal disposable non-property income are generated from an income-forecasting model, including interest rates, capacity utilisation, the government budget deficit and the Johannesburg Stock Exchange (JSE) share price index expressed in real terms. The model suggests that government deficits have persistent negative effects on

wealth effect. See Miles (1993), and, for a simple derivation, see Muellbauer and Lattimore (1995). 
subsequent income growth. This could reflect typical concerns for budget deficits followed by higher taxes or lower government expenditure; but these deficits may also signal political shocks. Past political unrest was often followed by higher social or military expenditure, which thus may serve as a proxy for a direct negative effect on growth through falling investment. This generates linkages between personal sector and government sector saving rates, an approach missing in previous work.

Nominal rises in interest rates and levels of real rates have strong negative effects on subsequent growth. The shift towards more market-oriented monetary policy in the 1980s appears to have weakened the influence of changes in nominal rates. Before the shift, high liquidity ratios and other quantitative methods of controlling credit growth were correlated with changes in nominal rates, exaggerating the apparent influence on growth of interest rates. After the shift, firms and households could refinance more easily, resulting in a weaker effect on expenditure from higher interest rates. However, while the coefficients on interest rates are lower, the greater volatility of interest rates in the market regime means the proportion of the variance of growth explained by interest rates remains high. Changes in capacity utilisation, proxying changes in labour market tightness have the expected positive effects on non-property incomes. Finally, the JSE index, sensitive to changes in the price of gold and other minerals, captures the positive role of improving terms of trade on income.

The model also takes account of important regime shifts. The model was estimated using a stochastic trend based on Koopman et al (1995), thereby capturing the decline in the growth rate in the 1980's as trade and financial sanctions and political difficulties increased. Using dummy indicators constructed from altering statutory liquidity ratios for commercial banks in the 1980s, it also captures the altered sensitivity of income growth to interest rates as the monetary policy regime changed. By incorporating important regime shifts in the economy, the resulting consumption function should be fairly immune from the Lucas critique.

\section{(ii) Wealth effects}

The personal sector illiquid and liquid wealth estimates used in the consumption model were constructed in Muellbauer and Aron (1999). These wealth data are shown in Figure 5, which plots the ratios to personal disposable non-property income of household debt and liquid assets, of directly-held illiquid financial assets (i.e. bonds and equities), total pension assets and private housing 
wealth. The household liquid assets ratio suggests a relatively stable ratio for the 1970s. In the 1980s however, there is a major fall in liquid asset holdings of households relative to non-property income. This coincided both with a fall in the personal sector saving ratio as implied by the income and expenditure accounts, and with a switch to saving in pension and retirement funds offering superior returns to those on liquid assets. Pension wealth has grown relative to income since the 1980s despite the fall in the personal sector saving ratio, and has hugely exceeding the growth in $\operatorname{debt}^{8}$. Yet, while it is now the single biggest asset, pension growth has been offset to a considerable degree by the decline of housing wealth relative to income. Note that the wealth effects on our model will be understated because we omit foreign assets accumulated illegally during the era of exchange controls on domestic residents. Similarly, there is no coverage of assets of unincorporated businesses in our measures of household assets, except for their inclusion in private housing stocks. For further discussion, see Muellbauer and Aron, 1999.

\section{(iii) Financial liberalisation}

Financial liberalisation was initiated following the de Kock Commission reports $(1978,1985)$, which advocated a more market-oriented monetary policy. Interest and credit controls were removed in 1980, and the banks' liquidity ratios were reduced substantially from 1983-85. Competition was increased in the mortgage market following the 1986 Building Societies Act, and amendments to the Act in 1987-88. Demutualisation and take-overs in 1989-90 consolidated the stronger competition in the credit market. In the 1990s pensions were increasingly used to provide additional collateral for housing loans; while access bond accounts allowed households to borrow and pay back flexibly up to an agreed limit set by their housing collateral from 1995. After the 1994 elections, more black South Africans obtained formal employment, particularly in the public sector, gaining access to credit

which they may previously have been denied. ${ }^{9}$ Exchange controls on non-residents were eliminated in early 1995: large non-resident capital inflows from mid-1994 induced a temporary endogenous

$8 \quad$ Among the factors behind this growth were the relaxation of restrictions on official pension funds (i.e. for government employees) which had prevented their holding of equities (Mouton Report, 1992); and the improvement in the returns on government and parastatal bonds with deregulation of interest rates after 1980 and the decline of inflation in the 1990s. 9 Note, however, that total formal employment of all races continued to decline. 
financial liberalisation. Finally, exchange controls on domestic residents, in existence since before the 1960s, were partially relaxed from 1997.

Financial liberalisation had a major impact on the ratio of consumption to income, but an even larger effect on the debt to income ratio. ${ }^{10}$ We provide an innovative treatment of financial liberalisation. A univariate indicator of financial liberalisation, FLIB, uses a monotonic and piecewise linear spline function, based on sequential institutional changes (for details see Aron and Muellbauer, 2000a). The FLIB function is introduced as a variable into both a debt equation and a consumption equation, and these two equations were jointly estimated, imposing cross-equation restrictions on the coefficients in the spline function. The estimated parameters for FLIB in the model reflect the key institutional changes in credit markets. In Figure 6, our estimated indicator shows strong rises in 1984, 1988 and 1995, with more moderate increases in 1989, 1990 and 1996.

In the consumption equation, the most important role for FLIB is a direct effect on the average propensity to consume, in part related to the lower mortgage deposit required by banks of home buyers. ${ }^{11}$ Further, a proxy for income uncertainty has a weaker effect on consumption when interacted with FLIB (i.e. the precautionary role of income uncertainty declines with financial liberalisation).

In the debt equation, the direct effect of FLIB on the debt to income ratio is significant but the effect of FLIB is dominated by interaction effects with asset to income ratios: debt rises as the collateral weight of housing assets rises with liberalisation ${ }^{12}$. However, there is a small offset: liquid assets have a reduced effect on debt with financial liberalisation, probably because mortgage lenders are then less constrained by the personal sector's liquid deposits.

10 Bayoumi (1993a, 1993b) and Taylor and Sarno (1998) use the debt to income ratio as an indicator of financial liberalisation, though it also depends on such factors as income, asset levels and interest rates.

11 We also interacted FLIB with housing assets expecting to find that housing wealth is effectively more spendable with liberalisation; however, the coefficient is hard to pin down accurately, probably because the housing asset to income ratio has been so trend-like since 1983 (see Figure 5).

12 It is noteworthy that the declining personal sector saving ratio and rising debt to income ratio due to financial liberalisation was accompanied by a falling house price to income ratio after the gold boom of the early 1980s. Possible reasons include poor growth, high real interest rates and emigration. In most other countries housing booms have followed significant financial liberalisation. 
It is noteworthy that both the consumption function and debt equation are subject to major structural breaks (failing Chow tests) when allowance is not made for financial liberalisation.

\section{(iv) Personal saving}

As shown in equation (2.2), the personal sector saving ratio is close to $\log (\mathrm{C} / \mathrm{PDI})$. Since our consumption function is formulated in terms of $\log (\mathrm{C} / \mathrm{PDNI})$, where PDNI is personal disposable non-property income, we use the following conversion to get from our consumption function to the personal sector savings rate:

$$
\mathrm{s} \cong-\log (\mathrm{C} / \mathrm{PDNI})-\log (\mathrm{PDNI} / \mathrm{PDI})
$$

Our quarterly consumption model applies equation (2.5) for 1970-1997, using our own generated income forecasts, our own liquid and illiquid asset variables, and our own indicator of financial liberalisation (Aron and Muellbauer, 2000a). We present here the long-run solution (in terms of nonstationary variables integrated of order 1):

$$
\begin{aligned}
\log (\mathrm{C} / \mathrm{PDNI})= & \text { constant }+0.33 \text { FLIB }+0.073 \log (\mathrm{PDI} / \mathrm{PDNI})+0.147 \text { RLADB } \\
& +0.068(\text { RHA + RIFA + RPAMA })-0.25 \text { RPRIMEMA }
\end{aligned}
$$

where FLIB is the financial liberalisation indicator. Note that $\log (\mathrm{PDI} / \mathrm{PDNI})$ is approximately equal to the ratio of personal disposable property to non-property income, and is included as a proxy for self-employment income, which is not separately available in the national accounts. The asset variables RLADB, RHA and RIFA, are respectively, ratios to current PDNI of liquid assets minus debt, gross housing assets and directly-held illiquid financial assets (end of previous quarter). RPAMA measures pension and insurance company assets owned by the personal sector, expressed as the previous quarter's four quarter moving average. The expected longer lag reflects the delays by which pension and insurance funds adjust contribution rates to changing asset values. 
RPRIMEMA is the four quarter moving average of the real interest rate using the prime rate charged by banks. ${ }^{13}$

Following equation (2.6), the long-run solution for the personal sector saving ratio is then derived as

$$
\begin{gathered}
\mathrm{s}=\text { constant }-0.33 \text { FLIB }+0.927 \log (\mathrm{PDI} / \mathrm{PDNI})-0.147 \text { RLADB } \\
-0.068(\text { RHA + RIFA + RPAMA })+0.25 \text { RPRIMEMA }
\end{gathered}
$$

It is noteworthy that the long-run saving ratio emphasises the role of wealth effects and financial liberalisation, typically neglected in conventional analyses. Liquid assets minus debt appear to be about twice as spendable as the various illiquid assets, which have similar degrees of spendability.

In Figure 7, equation (2.8) is illustrated by plotting $s$ against the explanatory variables weighted by their parameter estimates. This clarifies the longer-term trends as well as the extent to which short-run movements in the saving ratio, $\mathrm{s}$, are dominated by the volatility of property income, as reflected in PDI/PDNI.

Five points deserve emphasis, respectively concerning the role of financial liberalisation, monetary transmission, fiscal policy effects, saving and growth, and "piercing the veil". It appears from Figure 7 that there is a huge effect from financial liberalisation. Our model suggests that when comparing 1997 with 1983, financial liberalisation reduced the personal sector saving ratio by around 21 percent in the long-run, given PDI/PDNI, asset to income ratios and real interest rates. Since the average ratio of PDI to gross national disposable income during 1984-1997 was 0.62, see Figure 4, this implies a fall of 12.5 percentage points in the ratio of personal saving to gross national disposable income. However, Figure 7 also makes clear what the main offsetting factors were which make the falls in the saving ratios far less. As we shall see, some of these were influenced by financial liberalisation itself, implying that the partial equilibrium calculation overstates the general equilibrium effects.

The largest of these was the rise in PDI/PDNI, reflecting a rise relative to formal labour income in property and self-employment income in the unincorporated business sector. Whatever the other factors were, it is plausible that greater access to credit by the personal sector may have

13 The real interest rate is a borderline I(1) variable on annual data, though the quarterly moving average appears to be $\mathrm{I}(0)$. We therefore prefer to include it in the long-run solution. 
encouraged these developments. Figure 7 suggests that the fall in liquid assets minus debt was the second largest offsetting factor. One effect of financial liberalisation is to allow households to hold more debt and a lower level of liquid assets relative to income. Indeed, by the late 1980s, household debt exceeded liquid assets. However, this deterioration in households' portfolio position then tends to increase saving. Thirdly, financial liberalisation also contributed to the rise in real interest rates, since from the early 1980s credit demand was controlled more by high interest rates than by credit rationing. We find a rise in the real prime rate of interest of 1 percent has a direct positive effect on the personal sector saving ratio of 0.25 percent, see Figure 7 . The rise in real interest rates also helped to prevent a financial liberalisation-induced boom in asset prices, which would have led to a deterioration in the saving ratio. Figure 7 suggests that the rise in the value of illiquid assets relative to income in the 1990s did contribute to a fall in the saving ratio, but was balanced by the reverse effect between 1984 and 1990.

The full general equilibrium picture of the effect of financial liberalisation on $\mathrm{s}$ and on S/GDNI thus includes the direct effects, as well as more indirect effects via both financial liberalisation and the interest rate changes it induces on asset prices, the several income ratios, income growth expectations and the accumulation of assets. More comprehensive models are needed to quantify these effects.

The second point to emphasise concerns the nature of monetary policy transmission onto the personal sector. Our research emphasises multiple transmission channels: in addition to the direct effect shown in equation (2.7), the indirect effect via asset prices is probably even larger. While we have not estimated these effects of interest rates on asset prices in South Africa, theoretical considerations as well as empirical results for a range of other countries emphasise their relative importance (for a recent symposium on monetary policy emphasizing the asset price channel, see Federal Reserve Bank of Kansas, 1999).

There are two further interest rate influences. One is the effect of raised interest rates constraining expected income growth, which operates in the short-run. Eventually this feeds through into actual income, and hence into consumption. Further, when real interest rates are high, fewer households wish to borrow and instead save, lowering the proportion of credit-constrained households. These households are thus consuming less than current income. In our model, this lowers the short-run response of aggregate consumption to income growth. 
Third, the inclusion of expected income growth clarifies the channel of fiscal policy transmission onto personal saving. Our income-forecasting model suggests that a 1 percentage point reduction in the government deficit to GDP ratio raises personal disposable non-property income by around 1 percent in the long-run. Since income expectations and consumption adjust before actual incomes, such a reduction would result in a short-term decline in the ratio of personal saving to gross national disposable income. In the longer term, after disposable incomes have adjusted, there will be little effect on the ratio of personal saving to gross national disposable income, unless the ratio of personal to national income alters.

Fourth, our estimated model suggests that at given asset to income ratios and real interest rates, an increase in the steady state growth rate of income has little effect on the personal sector saving rate (see Deaton (1999), p.61, for a summary of the issues on the effect of growth on steady state personal saving).

Finally, we followed Poterba (1991) in testing whether dividend income had a zero direct effect on consumption after incorporating the equity wealth effect, as is implied if the "corporate veil is pierced". Dividend income was insignificant, suggesting that households saw an almost complete trade-off between increased dividends and a compensating fall in equity prices, and thus did not increase their consumption. This result, however, is subject to possible measurement error in the proxy for after-tax dividends ${ }^{14}$.

\section{Corporate Saving and Profits}

Corporations now dominate private saving, emphasising the importance of understanding the determinants of the corporate saving rate. In this paper, we examine the determinants of annual net corporate saving (relative to GNDI) for the period 1966 to 1997, including the role of dividend and other tax changes. Note that an increase in the net corporate saving ratio can come about both through a rise in corporate saving relative to profits, and a rise in the profit share in national income:

$$
\mathrm{CS} / \mathrm{GNDI}=\left(\mathrm{CS} / \mathrm{CP}^{\mathrm{net}}\right)\left(\mathrm{CP}^{\mathrm{net}} / \mathrm{GNDI}\right)
$$

14 We used the JSE dividend to price ratio, adjusted for tax, and multiplied by the estimated equity holdings. 
where CS is net corporate saving, and $\mathrm{CP}^{\text {net }}$ is corporate income (profits), net of tax and interest payments. There are multiple influences on each of the ratios on the right hand side. In order not to conflate these influences, we model the two ratios separately. Further, we break the second ratio, $\mathrm{CP}^{\text {net }} / \mathrm{GNDI}$, into $\left(\mathrm{CP}^{\text {net }} / \mathrm{CP}^{\text {gross }}\right) \cdot\left(\mathrm{CP}^{\text {gross }} / \mathrm{GNDI}\right)$, and model the second of these, thereby separating out tax effects in the first ratio from the share of gross profits in income (see section 3.2). This type of disaggregation extends the work of Poterba (1987) who examines only saving or dividend payments out of corporate profits.

Figure 8 illustrates all four ratios. The log ratio of corporate saving to net (after tax and net interest) profit rises until the late 1970s. It then fluctuates around the higher level, though since the early 1990s a declining trend appears. The ratio of net to gross profits, which largely reflects the ratio of company taxes to profits, shows little trend, but again a tendency to decline since the early 1990s. The share of gross profits in national income will be discussed in detail below. It is noteworthy that its upturn in the 1990s has been more than offset in recent years by higher taxation, so that net profits have fallen relative to national income since 1996.

\subsection{Corporate Saving Equation}

The received literature is largely a policy and empirical literature ${ }^{15}$, but generally lacks an agreed theoretical model. Poterba (1987) examines the mirror image of corporate saving, namely corporate dividend or payout equations, see also earlier work by Feldstein (1970, 1973) and King (1977), and summarises some of the alternative theories and the empirical literature for the U.S. and the U.K.. ${ }^{16}$ In the absence of an accepted theoretical model on dividend behaviour, Poterba argues for an error correction model for aggregate real dividends, where the target dividend is a function of equity earnings (using several different measures of earnings) and a tax discrimination variable, measured as the after-tax household income from a dividend payout relative to corporate retention, with associated capital gains. Such models focus on the links between cash flow and payouts. But, as Poterba acknowledges, another influence on dividend behaviour could come from the demand for retentions induced by corporate investment: if retentions offer a source of funding expected to be cheaper than equity or debt issues or bank borrowing, corporations may reduce dividend payments

15 There is only one previous econometric study for South Africa (Tsikata, 1998).

16 See also Bond et al (1995), for a cross-sectional study on company dividends. 
if they anticipate a higher cost of outside funds or greater profit earning opportunities (see also Caggese (1999), for a recent formal model of this type of saving motive). Poterba (1987) attempts to control for this influence by including in his dividend equation the effective tax rate on corporate investment and Tobin's q, but finds neither to be significant. In his U.S. results, the tax discrimination variable hovers around the 5 percent significance level over different samples and specifications. In the U.S., therefore, the relative tax burden on dividends and capital gains does appear to affect, but only weakly, the extent to which corporate earnings are distributed to shareholders.

Our net corporate saving measure covers saving by South African financial and non-financial corporations, as well as foreign affiliates of South African firms, and is defined as net corporate income less net tax and net interest paid (a relatively small component), and less net dividends, after provision for depreciation and inventory valuation adjustment. Poterba (1987) discusses adjusting a related measure of net saving, defined as undistributed profits less capital consumption, for inflationary gains on corporate debt. We make no inflation adjustment, but include inflation as a regressor in the corporate saving equation.

We analyse two tax effects, both associated with "piercing of the veil". First, the impact of dividend taxation, which underwent several changes in the period ${ }^{17}$. If corporations responded to the tax needs of their shareholders (pursuing a dividend policy to maximise after-tax returns of shareholders), then Poterba's tax discrimination variable - which for South Africa without a capital gains tax is simply measured as (1 - the dividend tax rate) - will show a negative effect on corporate saving (see Poterba, 1987). Second, without a capital gains tax, a positive inflation effect on corporate saving is expected - since tax distortion occurs when inflation is high, inflation increases the incentive to retain earnings. ${ }^{18}$ On the other hand, an inflation surprise, in principle, will serve to diminish debt, and hence reduce the need to save for debt repayments.

17 Between 1960 and 1990, dividends on directly-held equities were effectively taxed twice: once through corporation tax on company profits (out of which dividends are paid); and secondly, through a dividend tax on individuals, where one third of dividends were untaxed, and the remaining two thirds were taxed at the individual's marginal income tax rate. The dividend tax was temporarily abolished in 1990-93, and then replaced by a secondary dividend tax on companies.

18 Note that corporate saving may also have been encouraged by low or negative real after tax returns on alternative assets such as bonds or liquid deposits in an inflationary environment. 
Since corporate saving takes place largely to finance investment, when outside funds are expensive because real interest rates are high, or hard to obtain because of the denial of access to foreign finance, corporate saving should be higher. Furthermore, when expected income-growth rates are high, a higher rate of saving is expected since investment will then be particularly profitable (we compare results using forecast rates of income growth, from one year-ahead real PDNI per capita, and real GDP per capita forecasting equations, derived respectively, in Aron and Muellbauer, 2000a,b). There may also be short-run smoothing effects. In cyclical upturns and in gold price booms, when profits are temporarily high, one might expect companies to save a larger percentage of income. Finally, our financial liberalisation indicator, FLIB, described in section 2, is included to reflect the fact that household debt has its counterpart in corporate assets, particularly of financial corporations, and this might help to account for the relatively high corporate saving rate sustained into the 1990s.

We estimate an error correction model of the form

$$
\Delta \mathrm{y}_{\mathrm{t}}=\alpha_{0}+\Sigma \beta_{\mathrm{j}} \Delta \mathrm{x}_{\mathrm{j}, \mathrm{t}}+\beta_{0}\left(\Sigma \alpha_{\mathrm{j}} \mathrm{x}_{\mathrm{j}, \mathrm{t}-1}-\mathrm{y}_{\mathrm{t}-1}\right)+\varepsilon_{\mathrm{t}}
$$

where $\mathrm{y}$ is the $\log$ of corporate saving to profits, $\log \left(\mathrm{CS} / \mathrm{CP}^{\text {net }}\right)$. The $\mathrm{x}$ variables include RLTFLOW, the ratio of long-term capital inflows to GDP; TAXDISCR, defined as (1 - the dividend tax rate); RPRIME, the real prime rate of interest on borrowing; $\Delta \log (\mathrm{PC})$, the rate of change of consumer prices; and FLIB, the estimated indicator of financial liberalisation. These are all I(1) variables except for the real interest rate, which is borderline I(0) (see Table 1). Alternative cyclical indicators were also examined, including capacity utilisation in manufacturing, the gold terms of trade, and the $\log$ of real corporate profits, as well as the forecast rates of income growth noted above.

A general-to-specific testing procedure on annual data for 1966-97 gave the parsimonious equation shown in Table 2, column 1. The lag structure implies a speed of adjustment of around 0.5, meaning that half the effect of a change in a current dated regressor is felt in the first year.

Figure 9 shows the effects of the I(1) regressors weighted by their coefficients in the longrun solution ${ }^{19}$. We find that the tax effects on corporate saving are indeed two-fold. First, a rise in

Thus, the inflation effect may reflect both a desire to serve the tax needs of shareholders, and other considerations.

19 It achieves this by plotting $\left(\Delta \mathrm{y}_{\mathrm{t}}+\beta_{0} \mathrm{y}_{\mathrm{t}-1}\right)$ in equation (3.2) against 
personal tax rates on dividends (a fall in tax discrimination) raises corporate saving. Secondly, there is a positive effect from inflation, i.e. higher inflation particularly encourages corporations to retain earnings, given the lack of a capital gains tax. Thus, there is supporting evidence in favour of the sector saving on behalf of households, though, as noted above, the inflation effect may also reflect another motive. However, it is clear from the figure that variations in tax discrimination cannot explain the rise in corporate saving, though it may have helped sustain the level of corporate saving in the last 35 years.

The rise in inflation in the 1970 s accounts for a large part of the rise in the corporate saving rate. The fall in inflation in the 1990s was offset by higher real interest rates and financial liberalisation in consumer credit markets, which helped sustain corporate saving. The fall in the dividend tax rate (rise in tax discrimination) between 1979 and 1990 would have led to a decline in corporate saving but for the upward push from higher real interest rates and from financial liberalisation. The change from 1983 to 1997 in our measure of financial liberalisation for consumer credit markets raised the ratio of corporate saving to gross national disposable income by around 4 percentage points, given real interest rates, the ratio of net profits to national income and other variables.

Table 2 shows that three variables help explain the short-run dynamics of the log corporate saving ratio. One is the forecast rate of growth of real PDNI per capita. This is significant while the forecast rate of real GDP per capita is not (see column 2), possibly reflecting the fact that PDNI is dominated by wages and salaries. A rise in PDNI thus signals both higher final demand and more expensive labour input, capturing both an expansion and capital-deepening motive for investment which current corporate saving serves. Another short-run effect is the change in the ratio of international long-term capital inflows to GDP, capturing short-term changes in the access to foreign capital. Column 5 shows an alternative specification using total capital inflows ${ }^{20}$, which fits less well but otherwise gives similar results. There is also an indication of a negative effect on saving from the change in inflation, which may reflect the fall in the value of corporate debt with an inflation surprise, so reducing the need to save for debt-repayment purposes.

$\left(\beta_{\mathrm{j}} \Delta \mathrm{x}_{\mathrm{j}, \mathrm{t}}+\beta_{0} \alpha_{\mathrm{j}} \mathrm{x}_{\mathrm{j}-1}\right)$ for each I(1) variable.

20 From June, 1999, capital flows figures are published by the South African Reserve bank by functional type of investment rather than being categorised as long-term or short-term. Thus, we include here a measure for total flows. 
The equation has satisfactory diagnostics: there is no sign of residual autocorrelation or heteroscedasticity; it passes a Chow test for parameter stability splitting the sample halfway and Ramsey's RESET specification test. Columns 3 and 4 report estimates for 1966-93 and 1966-89 samples, which also indicate parameter stability. The first potential break (1966-93) captures the change of regime after democratic elections in April, 1994. The second potential break (1966-89) captures the change of monetary policy regime with a new central bank Governor, Dr. Stals; as well as the onset of political reforms after the release of Nelson Mandela in 1990. A linear combination of I(1) variables from Table 2, column 1, easily passes a Dickey-Fuller stationarity test.

\subsection{Corporate Profits Equation}

The profits ratio in equation (3.1), $\mathrm{CP}^{\text {net }} / \mathrm{GNDI}$, is broken into two components, $\left(\mathrm{CP}^{\text {net }} / \mathrm{CP}^{\text {gross }}\right) .\left(\mathrm{CP}^{\text {gross }} / \mathrm{GNDI}\right)$ (both are plotted in Figure 8$)$. Net profits are defined as corporate income, net of tax and interest payments. However, if tax and interest payments are regarded as items over which corporations have little control in the short-run, the former ratio, of after-tax and after-interest profits to profits before-tax and before-interest, can be regarded as given. Thus, our second model concentrates on identifying the determinants of the latter ratio, of gross corporate profits to gross national disposable income, or $\mathrm{CP}^{\text {gross }} / \mathrm{GNDI}$.

To derive an empirical equation for the share of profits in national disposable income, we begin with the standard analysis of a typical monopolistically competitive firm. This assumes constant average and marginal costs, $\mathrm{AC}=\mathrm{MC}$. The share of gross profits in total revenue is

$$
\mathrm{CP}^{\text {gross }} / \mathrm{PY}=(\mathrm{P}-\mathrm{AC}) \mathrm{Y} / \mathrm{PY}
$$

where $\mathrm{Y}$ is real GNDI. Defining the mark-up, the ratio of price, $\mathrm{P}$, to average or marginal cost, as $\mathrm{m}$ $=\mathrm{P} / \mathrm{AC}$, the profit share becomes

$$
\mathrm{CP}^{\text {gross }} / \mathrm{PY}=1-\mathrm{m}^{-1}
$$

While $\mathrm{m}$ is unknown, we have index number information on the main elements of $\mathrm{P}$ and $\mathrm{AC}$. We approximate $\log \left(\mathrm{CP}^{\text {gross }} / \mathrm{PY}\right)$ by a linear function of $\log (\mathrm{m})$. Assuming the cost share of labour to be 
$\alpha$, and the cost share of other inputs to be (1- $\alpha)$ - we proxy price movements in these inputs by the WPI, we can approximate the mark-up, m, by

$$
\mathrm{m} \cong \mathrm{m}_{\mathrm{o}} \mathrm{WPI} /(\mathrm{ULC})^{\alpha}(\mathrm{WPI})^{1-\alpha}=\mathrm{m}_{\mathrm{o}}(\mathrm{WPI} / \mathrm{ULC})^{\alpha}
$$

where WPI is the wholesale price index for domestically produced output, ULC is the index of unit labour cost and $m_{b}$ refers to the mark-up in the base year. For example, with plausible values of $\alpha=0.6$ and $\mathrm{m}_{\mathrm{o}}=1.5$, we would expect a coefficient around 1.2 in the regression of $\log \left(\mathrm{CP}^{\text {gross }} / \mathrm{GNDI}\right)$ on $\log (\mathrm{WPI} / \mathrm{ULC}),{ }^{21}$ where $\mathrm{CP}^{\text {gross }}$ is aggregate gross profits and GNDI is gross national disposable income.

The approximation in equation (3.6) of the output price to average cost ratio can be improved by including additional variables. One of these improves on WPI as an output price measure, the gold terms of trade (TOTRGOLD, defined as the ratio of the rand gold price divided by an index of import prices), since the gold price has only a relatively small weight in the wholesale price index of domestically produced goods and gold is a major revenue source. In the past, South Africa used substantial import surcharges to correct short-term balance of payments problems. Including the ratio of tariffs and surcharges to imports (RTARIF) reflects another component of the ratio of domestic output price to average cost, where the latter ratio falls as restrictions tighten. The level of real interest rate, RPRIME, potentially captures another aspect of costs for corporations holding floating debt. However, since this also covers financial corporations, which benefit from an interest rate rise, the effect of RPRIME on saving may well be small.

Assuming constant average costs neglects the role of fixed costs in reducing average costs as output increases. To correct for this, we include capacity utilisation, CAPUT, in the model. It is likely that as capacity utilisation rises, the profit share will rise as fixed costs decline relative to output.

The additional variables above take the size of the corporate sector as given. However, the size of the sector can vary with tax policy. Taxation can have an impact, not just on post-tax profits, but also on pre-tax profits. We control for two effects: one is a measurement effect, and the other, a real effect. First, if personal income tax rates are high relative to corporation tax, individuals with a business income have an incentive to become incorporated and fall under corporation tax instead. 
Thus, the difference between the highest personal income tax rate and corporation tax, TAXDIF, can be expected to have a positive effect on the share of profits in national income. Recent evidence for just such an effect in the U.S. comes from Gordon and Slemrod (1998). Secondly, a high ratio of taxes on companies relative to profits can act as a disincentive to earn or declare profits ${ }^{22}$. If the response to changes in tax rates or depreciation allowances was to shift the timing of declared income and expenditure into adjacent years, this would produce a short-run effect, only, which could be tested for.

Concerning dynamics, due to lags in production and lags in recording profits from accounting conventions, one might expect lagged as well as current GNDI to be relevant in the definition of the profit share. To correct for this, we include lagged GNDI amongst the explanatory variables. It is included in the form of $\Delta \log (\mathrm{GNDI})$ on the right hand side in order to preserve a coefficient of 1 on $\log (\mathrm{GNDI})$ in the long-run solution for $\log \left(\mathrm{CP}^{\text {gross }}\right)$.

Changes in the nominal interest rate also feature in this model. Crises such as the 1985 debt crisis have often been accompanied by sharp rises in nominal interest rates, which can affect gross profits by, for example, having a short-term impact on sales before production responds. One might therefore expect a negative effect from changes in the prime rate charged by banks.

To summarise, we estimated an error correction model, of the form in equation (3.2), for $\Delta \log \left(\mathrm{CP}^{\text {gross}} / \mathrm{GNDI}\right)$. The $\mathrm{x}$ variables classified as $\mathrm{I}(1)$, see Table 1 , are $\log (\mathrm{WPI} / \mathrm{ULC})$, $\log ($ TOTRGOLD), RPRIME, TAXDIF, RTARIF and $\log (\mathrm{CORPTAXR})$; and there are three I(0) variables, $\log (\mathrm{CAPUT}), \triangle \mathrm{PRIME}$ and $\Delta \log (\mathrm{GNDI})$. A general-to-specific testing procedure on annual data for 1971-97 ${ }^{23}$ gave the parsimonious equation shown in Table 3, column 1. We were able to accept the hypothesis that the coefficient on $\log \left(\mathrm{CP}^{\text {gross }} / \mathrm{GNDI}\right)_{-1}$ was -1 , simplifying the model to one with a levels dependent variable. The real prime rate was insignificant.

The analysis of the proximate determinants of the profit share highlights the role of the gold terms of trade and the ratio of wholesale prices to unit labour costs, see Figure 10, where the I(1) regressors are weighted by their coefficients. Both variables have declined in the 1990s, the latter

${ }_{21} \quad$ Note that $\partial \log \left(\mathrm{CP}^{\text {gross }} / \mathrm{PY}\right) / \partial \log (\mathrm{m})=1 /(\mathrm{m}-1)>1$.

22 We measure this tax ratio via $\log ($ CORPTAXR $)=\log (1+($ tax paid/net profits $))$. By using this measure of corporate taxation, we include the influences of variations in depreciation allowances and the differing tax regimes applied to mining companies, absent from the statutory corporate tax rate. For institutional details on tax regimes and depreciation allowances in the manufacturing sector, see Tsikata, 1998. 
because of stronger international competition and stronger trade unions (although, despite these negative effects, the profit share in national income staged a small recovery after 1994, with improved capacity utilisation and lower import tariffs). Another reason for some recovery of pre-tax corporate profits in the 1990's is suggested by a temporary fall in the ratio of company taxes to profits, and the rise in TAXDIF, defined as the highest rate of income tax minus corporation tax. The latter gives increased incentives for unincorporated businesses to incorporate, leading to a rise in reported corporate profits, but this compositional change is without much real significance for the economy as a whole.

Turning to the $\mathrm{I}(0)$ regressors, note that the interest rate terms simplify into a negative effect from the acceleration of the prime rate. In column 2, Table 3, we replace the acceleration in the prime rate by the change in the real rate, with similar results ${ }^{24}$. Capacity utilisation enters as a two year moving average. We could also accept (but have not imposed) the hypothesis of a coefficient of -0.5 on $\Delta \log (\mathrm{GNDI})$. This would be equivalent to omitting this term and defining the dependent variable as $\log \left(\mathrm{CP}^{\text {gross }} / \mathrm{GNDIma}\right)$, i.e. scaling by the two-year moving average of national income. The coefficient on $\Delta \log$ (WPIULC) is positive but insignificant and thus omitted from Table 3, suggesting that the output price to average cost effect enters largely as a one year lag. These results are consistent with lags in reporting profits or in production. The fact that only current values of the tariff and tax effects matter may be because rates of tax and tariff are typically known at the beginning of the year in which production takes place.

The model easily passes various specification tests for lack of residual autocorrelation, heteroscedasticity, a Chow test for stability over a mid-sample split and Ramsay's RESET specification test. Columns 3 and 4 report estimates for 1971-93 and 1971-89 samples, which also indicate parameter stability - see reasons for selecting these potential breaks in section 3.1. With six I(1) variables and at most 27 observations, the Johansen procedure (e.g. Johansen and Juselius, 1990) lacks power. However, a linear combination of I(1) variables from Table 3, column 1, easily passes a Dickey-Fuller test for stationarity.

\section{Concluding remarks and policy implications}

23 We were restricted to estimate from 1971, as ULC data begin in this year. 
This paper has explored the determinants of private saving in South Africa, separately examining personal (or household) and corporate sector saving behaviour over nearly three decades, from the late 1960 s to 1997 , and emphasising linkages between them.

Personal saving behaviour was examined by means of a quarterly solved-out consumption function for households. This allowed a fuller treatment of a range of extensions and approximations to theoretical behaviour than is usual in simple saving functions. Particular innovations were the inclusion of asset effects, financial liberalisation and income expectations, in addition to the more usual consumption determinants. The main conclusions from this model are fourfold. First, much of the rise in the consumption-to-income ratio has been the result of financial liberalisation, in part because of reduced down-payments for housing purchases. Second, real interest rates have significant direct negative effects on consumption, presumably because of the mix of substitution, income and user-cost-of-durables effects predicted by economic theory. The estimates throw important light on the monetary transmission mechanism, showing that there are multiple channels for the effect of interest rates on consumption expenditure. In addition to the direct effect, a rise in the real interest rates appears to have even larger indirect effects via asset prices, income and income expectations. In the absence of official wealth stock data, these apparently large asset effects have not previously been measured. Third, the inclusion of expected income growth clarifies the channel of fiscal policy transmission onto personal saving, generating linkages between personal sector and government sector saving rates, an approach missing in previous work. Fourth, the model suggests that the effect of a permanently higher growth rate on the personal saving ratio in South Africa is likely to be small, given real interest rates and asset to income ratios.

There is a striking paucity of literature on corporate saving behaviour, both in general, and applied to South Africa. We examined the determinants of annual net corporate saving relative to national income (GNDI) by disaggregating this ratio into two components, and investigating separately the determinants of net corporate saving with respect to net corporate income (or profits) and also gross corporate profits relative to GNDI. The key results from the profits equation are that the share of profits in national income rises with the ratio of wholesale prices to unit labour costs, the

$24 \quad$ At the suggestion of a referee, we tested that these interest rate effects are not largely a proxy for particular events such as the 1983-85 period of exchange rate unification, and subsequent debt crisis, when interest rates were particularly volatile. 
gold terms of trade, the difference between the highest tax rate on individuals and the rate of corporation tax and capacity utilisation, but falls with the ratio of company taxes to profits and with import tariffs (see Figure 10).

The main results from the corporate saving equation are that the rise in the inflation rate between the late 1960s and late 1980s was an important factor in explaining the rise in the share of corporate saving in net profits; while with the decline of inflation in the 1990s, the corporate saving rate has been bolstered by high real interest rates and financial liberalisation in consumer credit markets. Changes in personal tax rates on dividends play no role in explaining the rise in the corporate saving rate out of net profits, but they help account for some decline in the 1990s, Figure 9.

From these two models, and the log ratio of net to gross profits, we can derive a model for the log ratio of corporate saving out of national income, consistent with the corporate saving rate shown in Figure 3. For example, the 1980 peak in Figure 3 can now be understood to be the result of the peak in the share of profits associated with the gold price boom, and not the result of any significant rise in the propensity to save out of profits.

There are important interlinkages between household and corporate saving. A key question is whether the well-known stability of private saving can be fully attributed to households "piercing the corporate veill". We tested this hypothesis in both the personal and corporate saving models, and found evidence for the "piercing of the veil" in both cases: household expenditure appears to respond to the value of equities rather than to after-tax dividend payments, while the corporate tax rate is influenced by the personal dividend tax and by inflation.

However, the significant role of inflation in explaining the secular rise in the corporate saving rate out of net profits is only partly explained by corporations serving the tax needs of their shareholders. Other reasons include poor returns on alternative assets in an inflationary environment. Moreover, the role of changing dividend taxation should not be exaggerated - quite apart from the fact that, as we have seen, its variations cannot explain the secular rise in the corporate saving rate. Around 80 percent of equities in 1980 and around 90 percent in 1995 held on behalf of the personal sector were held by pension funds and were thus tax-exempt ${ }^{25}$. The above tests do not indicate the

25 Pensions paid out to individuals are subject to income tax. However, since pension income is received at a time when other income is low or non-existent, low marginal tax rates will tend to apply. 
extent of sectoral offset: but even if households saw perfectly through the corporate budget constraint, "piercing of the veil" is only one factor in explaining the sectoral shifts.

Indeed, our personal and corporate sector models both show very clearly the importance of other economic factors in changing sectoral saving behaviour. These are of two types. First, there are factors which move household and corporate saving rates out of national income in opposite directions, with differing degrees of offset. Perhaps most obviously, the shares of corporate profits and of personal disposable income in national income are negatively correlated, see Figures 4 and 10. Factors causing such negative correlation are gold booms and other causes of the procyclical pattern of the profit share, and strengthening union power, which raises labour's share and lowers the profit share. To the extent that there is some stability in the sectoral saving ratios out of sectoral income, the two sectoral saving ratios out of national income will be negatively correlated.

There are also factors that can move household and corporate saving rates out of their respective sectoral incomes in opposite directions. The most important of these is financial liberalisation. While there are general equilibrium effects which make it complicated to quantify the degree of offset, our results suggest that financial liberalisation reduced personal saving far more than it raised corporate saving. Inflation surprises decrease corporate saving and increase measured household saving (via wealth effects and measured disposable income, since measured interest income rises with higher nominal interest rates).

Second, other factors cause a positive correlation between the two savings rates out of sectoral income: both increasing, or both decreasing. Higher real interest rates affect both corporate and personal sector saving rates positively, given income and growth. Other factors can be ambiguous. A rise in government saving reduces the personal saving rate out of personal income by raising income expectations (which we modelled separately), given current income, and also to the extent that it results in lower real interest rates. The income expectations effect of a rise in government saving on the corporate saving rate is in the opposite direction, though the real interest rate effect is in the same direction as for households.

The net effect of all these factors suggested by our models is thus rather more complex than the simple "piercing of the veil" story. This view suggests there are good reasons for concern not only about reversing the recent trend of government dissaving, but also with the compositional change in private saving, and the worrying decline in both private savings ratios from 1995. 
Our models represent a significant advance on earlier partial equilibrium models of saving. However, to examine the general equilibrium effects for monetary transmission implications, these richer partial models should be included in larger models, in particular to trace through the real interest rate effects via asset price changes for bonds, housing and equities. Such work should address also risk premia more explicitly than we have been able to do.

There have been extensive debates on the effects of financial liberalisation on private saving. Our results concur with findings in the empirical survey in Fry (1995), ch.8: if financial liberalisation increases the availability of consumer credit, private saving tends to decline.

Policy changes in the new millennium with a bearing on savings behaviour in South Africa include the introduction of capital gains taxation on securities directly held by households. The regime announced is stringent with minimal allowances and no inflation indexing. Since we cannot reject the hypothesis that the "corporate veil is pierced", our models predict little impact on total private saving; they suggest some increase in personal sector saving, with a reduction in corporate saving (since corporate retentions resulting in taxable capital gains for households will now be less attractive to households). An important change is the transition towards inflation targeting and the decision to issue inflation-indexed bonds. These moves should improve the transparency and stability of policy, dampen inflationary expectations, and reduce risk premia, and so lower real interest rates.

The recent fall in the corporate saving ratio from about 1995, despite rises in the real interest rate, appears consistent with our model (see Figure 9, and, for the real interest rate history, Figure 2). However, if real interest rates are to be much reduced, our partial equilibrium models suggest that both personal and corporate saving rates out of (higher) sectoral incomes will fall still further. Taking further system feedbacks into account, the asset price effects of lower interest rates will reinforce the fall in personal sector saving rate; while the effect of a higher growth rate on saving is probably fairly small (for given asset to income ratios). For corporations, however, the growth effects on saving from lower interest rates are likely to be larger, and computing their size has great current policy relevance. Encouraging corporate saving would seem to be particularly important if the sustainability of "foreign savings" remains uncertain due to the volatility of capital inflows, if government saving improves only slowly, and if household saving should remain low.

Even without embedding our models in a full macroeconometric model, we can draw some policy conclusions - supplementing these models by simple hypotheses about, for example, the 
effect on asset prices of higher interest rates. One possible measure related to our model concerns prudential regulation limiting the degree to which companies can take on short-term foreign debt. Another concerns corporate taxation and depreciation allowances, where more generous treatment encourages investment and companies to earn more profit. Since corporations have much higher saving rates than households, this should raise the private saving rate out of national income.

Returning to the personal sector, it is clear that despite the direct and indirect effects of high real interest rates in the 1990s, net household saving has fallen to very low levels, and this is mainly due to financial liberalisation. The South African financial system encourages borrowing by the personal sector to an excessive degree - in the sense that the high interest rates considered necessary to restrain consumer credit and spending have also restrained investment and economic growth in the 1990s. Attention should be given to tightening prudential controls, both to allow for the possibility of macroeconomic risk, and of a shock to the financial system, for instance, via a major fall in asset values. Prudential controls should not only stabilise the financial system, but keep individual default rates to reasonably low levels, particularly for new consumers, many of whom may have little experience of risk-management. One possible move would be to impose higher risk weights for mortgage loans with high loan to value ratios. Another area for tightening regulations concerns the use of pensions for housing collateral. While current regulations may have implications for reducing the housing deficit, forcing income risk, pension risk and housing risk to be so correlated, violates the general notion of spreading risk. Housing policies which encourage the rental sector would help to reduce over-borrowing by young and middle income households.

Apart from encouraging prudent lending by the financial sector, there is potentially a role for tax incentives to encourage household saving. Though we have not investigated a separate role for the rate of return on assets, as opposed to the borrowing rate, our evidence is at least consistent with the idea that extending the generous tax treatment of pensions to some other saving products would raise the personal sector saving rate. Such schemes may help to install a long-term culture of saving, though it is fair to say that empirical evidence for the U.S. has not found large aggregate saving effects (e.g. Hubbard and Skinner, 1996, and other papers in this volume). 


\section{REFERENCES}

Aron, Janine and John N. J. Muellbauer. 2000a. "Financial Liberalisation, Consumption and Debt in South Africa." Working Paper Series, Centre for the Study of African Economics, Oxford University (forthcoming).

Aron, Janine and John N. J. Muellbauer. 2000b. "Inflation and Output Forecasts for South Africa:

Monetary Transmission Implications." Working Paper Series, Centre for the Study of African Economics, Oxford University (forthcoming).

Bandiera, O., G. Caprio, P. Honohan, and F. Schianterelli. 1998. "Does Financial Reform Raise or Reduce Saving?" Mimeograph, The World Bank.

Banerjee, A., J. Dolado, J. Galbraith and D. Hendry. 1993. "Co-Integration, Error Correction and the Econometric Analysis of Non-Stationary Data." Oxford: Oxford University Press.

Barr, G. and B. Kantor. 1994. "The Changing Pattern of Savings in South Africa 1970-91.” Journal of Studies in Economics and Econometrics 18(3): 59-76.

Bayoumi, T. 1993a. "Financial Deregulation and Consumption in the United Kingdom." Review of Economics and Statistics 75(3): 536-39.

Bayoumi, T. 1993b. "Financial Deregulation and Household Saving." Economic Journal 103 (421): 1432-43.

Bond, S., L. Chennells and M. Devereux. 1995. "Company Dividends and Taxes in the U.K.." Fiscal Studies 16: 1-18.

Campbell, J. Y. and G. Mankiw. 1989. "Consumption, Income and Interest Rates; Reinterpreting the Time Series Evidence." in O. J. Blanchard and S. Fischer (eds.), NBER Macroeconomic Annual, 1989, Cambridge, Mass: MIT Press, 185-216.

Campbell, J. Y. and N. G. Mankiw.1991. "The Response of Consumption to Income: A CrossCountry Investigation." European Economic Review 35: 715-21.

David, P. A. and J. L. Scadding. 1974. "Private Savings: Ultrarationality, Aggregation and Denison's Law." Journal of Political Economy 82: 225-49.

Davidson, J., D. F. Hendry, F. Srba and S. Yeo. 1978. "Econometric Modelling of the Aggregate Time-Series Relationship Between Consumers' Expenditure and Income in the United Kingdom." Economic Journal 88: 661-92.

de Kock, G. 1978. Commission of Inquiry into the Monetary System and Monetary Policy in South Africa, Interim Report, Government Printer, Pretoria.

de Kock, G. 1985. Commission of Inquiry into the Monetary System and Monetary Policy in South Africa, Final Report, Government Printer, Pretoria.

Deaton, Angus. 1999. "Saving and Growth." in Schmidt-Hebbel, K., and L. Serven (eds.).1999. The Economics of Saving and Growth. Cambridge: Cambridge University Press, 33-70.

Dickey, D. and Fuller, W. 1979. "Distribution of the Estimators for Autoregressive Time Series with a Unit Root." Journal of the American Statistical Association 74: 427-431.

Engle, R. F. and C. W. J. Granger. 1987. "Cointegration and Error Correction: Representation, Estimation and Testing." Econometrica 55: 251-276.

Federal Reserve Bank of Kansas. 1999. New Challenges for Monetary Policy. Jackson Hole, Wyoming, Symposium .

Feldstein, M. S. 1970. "Corporate Taxation and Dividend Behaviour." Review of Economic Studies 37: 57-72.

Feldstein, M. S. 1973. "Tax Incentives, Corporate Saving, and Capital Accumulation in the United States." Journal of Public Economics 2: 159-71.

Fry, Maxwell. 1995. Money, Interest, and Banking in Economic Development. Baltimore and London: Johns Hopkins University Press. Second Edition.

Gordon, R. H. and J. Slemrod. 1998. "Are 'Real Responses to Taxes Simply Income Shifting between Corporate and Personal Tax Bases?" NBER Working Paper 6576, May. 
Hall, R. E. 1978. "Stochastic Implications of the Life Cycle-permanent Income Hypothesis: Theory and Evidence." Journal of Political Economy 96: 971-87.

Hall R. E. and F. S. Mishkin.1982. "The Sensitivity of Consumption to Transitory Income: Estimates from Panel Data on Households." Econometrica 50: 461-81.

Hendry D. F. and T. Von Ungern Sternberg. 1981. "Liquidity and Inflation Effects on Consumer's Expenditure." in A Deaton, Essays in Theory and Measurement of Consumers' Behaviour, Cambridge: Cambridge University Press, 237-260.

Honohan, Patrick. 1999.'Financial Policies and Saving." in Schmidt-Hebbel, K., and L. Serven (eds.).1999. The Economics of Saving and Growth. Cambridge: Cambridge University Press, 71-106.

Hubbard, R. Glenn and Jonathan S. Skinner. 1996. "Assessing The Effectiveness Of Saving Incentives." Journal of Economic Perspectives 10 (4): 73-90.

Johansen, S. and Juselius, K. 1990. "The Full Information Maximum Likelihood Procedure for Inference on Cointegration - with Applications." Oxford Bulletin of Economics and Statistics 52: 269-210.

Kaldor, N. 1957. “A Model of Economic Growth.” Economic Journal 57: 591-624.

King, M. A. 1977. Public Policy and the Corporation. London: Chapman and Hall.

Kingdon, Geeta G. and John B. Knight. 1999. "Unemployment in South Africa: the Nature of the Beast." Mimeograph, Centre for the Study of African Economies, University of Oxford.

Klasen, Stephan. 1997. "Poverty and Inequality in South Africa." Mimeograph, Common Security Forum, Centre for History and Economics, King's College, Cambridge.

Koopman, S. J., A. C. Harvey, J. A. Doornik and N. Shephard.1995. Structural Time Series Analyser, Modeller and Predictor (STAMP), London: Chapman and Hall.

Jappelli, Tullio and Marco Pagano. 1994. "Saving, Growth and Liquidity Constraints." Quarterly Journal of Economics 109: 83-109.

Lucas, R. E. 1976. "Econometric Policy Evaluation: a Critique." Carnegie-Rochester Conference Series Supplement to the Journal of Monetary Economics 1: 19-46.

Lucas, R. E. 1981. "Studies in Business Cycle Theory." Cambridge: Mass, MIT Press.

MacKinnon, J. 1991."Critical Values for Cointegration Tests." in Engle, R. and C. Granger (eds.), (1991), Long-run Economic Relationships: Readings in Cointegration. Oxford: Oxford University Press.

Miles, D. 1993. Housing, Financial Markets and the Wider Economy, New York: Wiley.

Moll, Peter. 1998. "Discrimination is Declining in South Africa, but Inequality is not." Working Paper no. 5, South African Network for Economic Analysis, Cape Town.

Mouton Report, "Report of the Committee of Investigation into a Retirement Provision System for South Africa." November, 1992.

Muellbauer, John N. J. and Janine Aron. 1999. "Estimates of Personal Sector Wealth for South Africa.@ Working Paper Series 99.17, Centre for the Study of African Economics, Oxford University.

Muellbauer J. N. J. and R. Lattimore. 1995. "The Consumption Function: A Theoretical and Empirical Overview." in H. Pesaran and M. Wickens (eds), Handbook of Applied Econometrics, Oxford: Blackwell, 221-311.

Muellbauer J. N. J. and A. J. Murphy. 1995. "Explaining Regional Consumption in the U.K." Mimeograph, Nuffield College, Oxford.

Pretorius, C. J. and S. Knox. 1995. "Private Consumption Expenditure in the Macro-Model of the Reserve Bank." Quarterly Bulletin, South African Reserve Bank, June.

Patterson, K. D. 1984. "Net Liquid Assets and Net Illiquid Assets in the UK Consumption Function: Some Evidence for the UK." Economic Letters, 14(4): 389-395.

Poterba, J. M. 1987. "Tax Policy and Corporate Saving." Brookings Papers on Economic Activity 2: 455-503. 
Poterba, J. M. 1991. "Dividends, Capital Gains and the Corporate veil: Evidence from Britain, Canada and the United States." in B.D. Douglas and J.B. Shoven (eds.) National Saving and Economic Performance, 49-71, Chicago: University of Chicago Press.

Prinsloo, J. W. 1994. "Private Sector Saving in South Africa." Quarterly Bulletin, South African Reserve Bank, September.

Prinsloo, J. W. 1997."Corporate and Household Saving in South Africa: a Macroeconomic Perspective." Mimeograph, South African Reserve Bank.

RDP Office. 1995. Key Indicators of Poverty in South Africa, Pretoria, RDP Office.

Schmidt-Hebbel, K., and L. Serven. 1997. "Saving Across the World: Puzzles and Policies", World Bank Discussion Paper No. 354, The World Bank.

Schmidt-Hebbel, K., and L. Serven.1999. The Economics of Saving and Growth. Cambridge: Cambridge University Press.

Sarno, L. and M. Taylor. 1998. "Real Interest Rates, Liquidity Constraints and Financial Deregulation: Private Consumption Behaviour in the U.K." Journal of Macroeconomics 20: 221-242.

Tsikata, Y., (1998), "Savings in South Africa: an Empirical Investigation”, Mimeograph, The World Bank.

Zellner, A.., D. S. Huang and L. C. Chau. 1965. "Further Analysis of the Short-run Consumption Function with Emphasis on the Role of Liquid Assets." Econometrica 33: 571-81. 
Table 1:

Statistics and Variable Definitions

\begin{tabular}{|c|c|c|c|c|c|}
\hline Variable & Definition of Variable & Mean & Std. Deviation & $I(1)$ & $I(2)$ \\
\hline$(1966-1997)$ & Corporate Savings Equation & & & & \\
\hline$\Delta \log \left(\mathrm{CS} / \mathrm{CP}^{\text {net }}\right)$ & \begin{tabular}{|c|} 
Growth rate of ratio of corporate saving to \\
GNDI
\end{tabular} & 0.0287 & 0.1507 & $-7.78 * *$ & - \\
\hline $\log \left(\mathrm{CS} / \mathrm{CP}^{\text {net }}\right)$ & Log of ratio of corporate saving to GNDI & -0.6074 & 0.4238 & -2.12 & $-7.784 * *$ \\
\hline$\Delta$ RLTFLOW & $\begin{array}{c}\text { Change in ratio of long-term capital flows } \\
\text { to GDP }\end{array}$ & 0.0003 & 0.0051 & $-6.76^{* *}$ & - \\
\hline$\Delta$ RTOTFLOW & $\begin{array}{c}\text { Change in ratio of total capital flows to } \\
\text { GDP }\end{array}$ & -0.00004 & 0.0073 & $-5.67 * *$ & - \\
\hline TAXDISCRma & $\begin{array}{l}\text { two year moving average of tax } \\
\text { discrimination, defined as } \\
\text { (1- effective rate of dividend tax) }\end{array}$ & 0.7086 & 0.1126 & $4.55 * *$ & - \\
\hline FLIB & $\begin{array}{l}\text { Estimated indicator of financial } \\
\text { liberalisation (section } 2.3,(\mathrm{~d}))\end{array}$ & 0.1574 & 0.2210 & - & - \\
\hline RPRIME & real prime interest rate/100 & 0.0370 & 0.0425 & $-3.72 *$ & $-4.44 * *$ \\
\hline$\Delta \log (\mathrm{PC})$ & Inflation rate (consumption deflator) & 0.1035 & 0.0379 & -2.17 & $-4.92 * *$ \\
\hline$\Delta^{2} \log (\mathrm{PC})$ & Acceleration of prices (cons. deflator) & 0.0013 & 0.0179 & $-4.92 * *$ & - \\
\hline$\Delta \log (\mathrm{RYN}(+1))^{\text {forcst }}$ & Forecast real income growth rate & 0.0042 & 0.0312 & $-3.67 *$ & \\
\hline$\Delta \log (\mathrm{RGDP}(+1))^{\text {forcst }}$ & Forecast real GDP growth rate & 0.0243 & 0.0246 & $-4.34 * *$ & \\
\hline$(1971-1997)$ & Corporate Profits Equation & & & & \\
\hline $\log \left(\mathrm{CP}^{\text {gross }} / \mathrm{GNDI}\right)$ & $\log ($ gross profits/GNDI) & -1.9178 & 0.1937 & -1.5272 & $-4.37 * *$ \\
\hline $\log ($ CAPUTma $)$ & $\begin{array}{c}\text { Log of manufacturing capacity utilization } \\
\text { index (4 quart. MA) }\end{array}$ & 4.4098 & 0.0253 & $-7.03 * *$ & - \\
\hline $\log ($ CORPTAXR $)$ & \begin{tabular}{|c|} 
Log of the ratio of corporate tax payments \\
to pre-tax and interest corporate profits
\end{tabular} & 0.4981 & 0.0886 & -2.91 & $-5.0569 * *$ \\
\hline RTARIF & $\begin{array}{c}\text { (tariffs + import surcharges)/ value of } \\
\text { imports }\end{array}$ & 0.0720 & 0.0189 & -1.8910 & $-4.73 * *$ \\
\hline Log(TOTRGOLD) & $\begin{array}{c}\text { Log real rand price of gold (deflated by } \\
\text { import price index) }\end{array}$ & -0.0353 & 0.2467 & $-3.24 *$ & $-4.29 * *$ \\
\hline Log(WPIULC) & \begin{tabular}{|c|} 
Log ratio of wholesale price index \\
(domestically-produced output) and unit \\
labour cost in non-agric. Sectors
\end{tabular} & -0.4303 & 0.1017 & -3.25 & $-4.17 * *$ \\
\hline TAXDIF & $\begin{array}{l}\text { (max. personal rate of income tax } \\
\text { - corp. tax)/100 }\end{array}$ & 0.0844 & 0.0946 & -1.90 & -2.41 \\
\hline$\Delta \log (\mathrm{GNDI})$ & $\begin{array}{c}\begin{array}{c}\text { Growth rate of growth national disposable } \\
\text { income }\end{array} \\
\end{array}$ & 0.1448 & 0.0412 & $-4.29 *$ & $-6.84 * *$ \\
\hline$\Delta^{2}(\mathrm{PRIME})$ & Acceleration in (prime interest rate/100) & 0.0001 & 0.0364 & $-5.82 * *$ & - \\
\hline$\Delta$ RPRIME & change in the real prime interest rate/100 & 0.0033 & 0.0354 & $-4.26 * *$ & - \\
\hline $\log ($ ECTRav $)$ & $\begin{array}{l}\log \text { of the effective corporate tax rate } \\
\text { (averaged cross two years) }\end{array}$ & 3.7957 & 0.1177 & -1.82 & -2.64 \\
\hline
\end{tabular}

1. For a variable $X$, the augmented Dickey Fuller (1981) statistics is the t ratio on $\pi$ from the regression:

$\Delta \mathrm{X}_{\mathrm{t}}=\pi \mathrm{X}_{\mathrm{t}-1}+\Sigma_{\mathrm{i}=1}^{\mathrm{k}} \theta_{\mathrm{i}} \Delta \mathrm{X}_{\mathrm{t}-\mathrm{i}}+\psi_{0}+\psi_{1} \mathrm{t}+\varepsilon_{\mathrm{t}}$, where $\mathrm{k}$ is the number of lags on the dependent variable, $\psi_{0}$ is an intercept term and $\mathrm{t}$ is a trend. The kth-order augmented Dickey-Fuller statistic is reported, where $\mathrm{k}$ is the last significant lag of the * fix lags employed. The trend was included only if significant. For null order I (2), $\Delta \mathrm{X}$ replaces $\mathrm{X}$ in the equation above. Asterisks * and ** denote rejection at the $5 \%$ and $1 \%$ critical values. Critical values with constant, and with and without trend, are obtained from MacKinnon (1991). 
Table 2: $\quad$ Corporate Saving Equation Estimates

\begin{tabular}{|c|c|c|c|c|c|}
\hline $\begin{array}{l}\text { Dependent variable } \\
\Delta \log \left(\mathrm{CS} / \mathrm{CP}^{\mathrm{net}}\right)\end{array}$ & $\begin{array}{c}1 . \\
1966-1997 \\
\end{array}$ & $\begin{array}{c}2 . \\
1966-1997 \\
\end{array}$ & $\begin{array}{c}3 . \\
1966-1993 \\
\end{array}$ & $\begin{array}{c}4 . \\
1966-1989 \\
\end{array}$ & $\begin{array}{c}5 . \\
1966-1997 \\
\end{array}$ \\
\hline \multicolumn{6}{|l|}{ Regressors } \\
\hline Intercept & $-0.38(1.22)$ & $-0.11(0.31)$ & $-0.33(0.67)$ & $-0.40(0.46)$ & $-0.42(1.23)$ \\
\hline $\log \left(C S / C P^{\text {net }}\right)(-1)$ & $-0.53(3.58)$ & $-0.43(2.53)$ & $-0.50(3.09)$ & $-0.53(2.35)$ & $-0.55(3.34)$ \\
\hline$\Delta$ RLTFLOW & $-3.47(3.30)$ & $-3.41(2.71)$ & $-4.34(3.33)$ & $-4.25(2.91)$ & - \\
\hline$\Delta$ RTOTFLOW & - & - & - & - & $-6.99(2.17)$ \\
\hline TAXDISCRma & $-1.29(2.71)$ & $-1.05(2.06)$ & $-1.23(1.78)$ & $-1.25(1.17)$ & $-1.30(-2.47)$ \\
\hline FLIB(-1) & $0.57(2.11)$ & $0.52(1.75)$ & $0.55(1.11)$ & $0.23(0.25)$ & $0.60(2.00)$ \\
\hline RPRIME & $3.80(2.56)$ & $1.59(1.13)$ & $3.53(2.19)$ & $3.87(1.87)$ & $3.63(2.18)$ \\
\hline$\Delta \log (\mathrm{PC})$ & $7.30(3.24)$ & $4.68(1.89)$ & $6.75(2.73)$ & $7.39(2.00)$ & $7.66(3.08)$ \\
\hline$\Delta^{2} \log (\mathrm{PC})$ & $-2.97(2.05)$ & $-1.59(1.10)$ & $-3.06(-1.78)$ & $-3.04(-1.56)$ & $-2.93(-1.83)$ \\
\hline$\Delta \log (\mathrm{RYN}(+1))^{\text {forcst }}$ & $3.64(2.29)$ & - & $3.24(1.93)$ & $3.51(1.65)$ & $3.84(2.18)$ \\
\hline$\Delta \log (\mathrm{RGDP}(+1))^{\text {forcst }}$ & - & $0.98(0.60)$ & - & - & - \\
\hline \multicolumn{6}{|l|}{ Diagnostics } \\
\hline Standard Error & 0.1138 & 0.1250 & 0.1180 & 0.1291 & 0.1259 \\
\hline $\mathrm{R}^{2}$ & 0.577 & 0.489 & 0.612 & 0.594 & 0.482 \\
\hline Adj.: ${ }^{2}$ & 0.430 & 0.311 & 0.448 & 0.377 & 0.302 \\
\hline DW & 2.20 & 2.27 & 2.16 & 2.17 & 2.26 \\
\hline LM1 & 0.42 & 0.72 & 0.20 & 0.34 & 0.72 \\
\hline LM2 & 0.34 & 2.89 & 0.21 & 0.43 & 0.55 \\
\hline Ramsey Reset Test & $0.02[0.89]$ & $0.40[0.53]$ & $0.03[0.86]$ & $0.21[0.86]$ & $0.10[0.76]$ \\
\hline CHOW & $1.297[0.320]$ & $0.998[0.483]$ & $0.668[0.715]$ & $1.198[0.428]$ & 1.158 [0.389] \\
\hline
\end{tabular}

1. Absolute values of asymptotic t-ratios in parentheses. P-values for Chow and Ramsey tests in square brackets.

2. Definitions of the variables, and statistics, are given in Table 1.

3. Equation 1 uses the annualised 4-quarter ahead forecast real income growth rate estimated using quarterly data and a stochastic trend in STAMP 5.0 (Koopman et al, 1995); while Equation 2 replaces this by the forecast real GDP per capita growth rate, estimated in the same manner (see Aron and Muellbauer, 2000b). Equations 3 and 4 use shorter samples, defined by particular regime breaks, to test for the parameter stability of equation 1 . Equation 5 replaces the long-term flows to GDP variable in Equation 1 by total flows. 
Table 3: $\quad$ Corporate Profits Equations Estimates

\begin{tabular}{|c|c|c|c|c|}
\hline $\begin{array}{l}\text { Dependent variable } \\
\log \left(\mathrm{CP}^{\text {gross }} / \mathrm{GNDI}\right)\end{array}$ & $\begin{array}{c}1 . \\
1971-1997 \\
\end{array}$ & $\begin{array}{c}2 \\
1971-1997 \\
\end{array}$ & $\begin{array}{c}3 \\
1971-1993 \\
\end{array}$ & $\begin{array}{c}4 \\
1971-1989 \\
\end{array}$ \\
\hline \multicolumn{5}{|l|}{ Regressors } \\
\hline Intercept & $-6.54(4.34)$ & $-8.78(3.85)$ & $-7.23(5.02)$ & $-5.82(4.16)$ \\
\hline $\log$ (CAPUTma) & $1.26(3.72)$ & $1.75(3.37)$ & $1.40(4.37)$ & $1.32(3.64)$ \\
\hline $\log ($ CORPTAXR) & $-0.38(3.49)$ & $-0.36(2.47)$ & $-0.41(4.18)$ & $-0.49(3.03)$ \\
\hline RTARIF & $-2.77(4.99)$ & $-1.88(2.53)$ & $-2.48(4.98)$ & $-2.67(4.51)$ \\
\hline $\log$ (TOTRGOLD) & $0.56(13.98)$ & $0.58(11.26)$ & $0.57(15.73)$ & $0.56(11.72)$ \\
\hline $\log$ (WPIULC)-1 & $1.18(10.21)$ & $1.07(7.45)$ & $1.02(6.59)$ & $0.83(3.87)$ \\
\hline TAXDIF & $0.72(5.39)$ & $0.83(4.91)$ & $0.82(6.37)$ & $0.99(4.71)$ \\
\hline$\Delta \log (\mathrm{GNDI})$ & $-0.63(3.12)$ & $-0.88(2.91)$ & $-0.61(3.41)$ & $-0.64(3.08)$ \\
\hline$\Delta^{2}(\mathrm{PRIME})$ & $-0.88(4.75)$ & - & $-0.81(4.81)$ & $-0.81(4.22)$ \\
\hline$\Delta$ RPRIME & - & $-0.80(2.58)$ & - & - \\
\hline \multicolumn{5}{|l|}{ Diagnostics } \\
\hline Standard Error & 0.0309 & 0.0396 & 0.0269 & 0.0296 \\
\hline $\mathrm{R}^{2}$ & 0.982 & 0.971 & 0.989 & 0.986 \\
\hline Adj.R ${ }^{2}$ & 0.975 & 0.958 & 0.982 & 0.975 \\
\hline DW & 2.49 & 2.11 & 2.77 & 2.66 \\
\hline LM1 & 2.86 & 0.18 & 2.86 & 2.63 \\
\hline LM2 & 2.62 & 0.21 & 3.24 & 6.52 \\
\hline Ramsey Reset Test & $0.00[0.96]$ & $0.00[0.97]$ & $0.01[0.91]$ & $0.19[0.68]$ \\
\hline CHOW & $0.27[0.97]$ & $0.87[0.58]$ & $1.20[0.44]$ & $0.78[0.71]$ \\
\hline
\end{tabular}

1. Absolute values of asymptotic t-ratios in parentheses. P-values for Chow and Ramsey tests in square brackets.

2. Definitions of the variables, and statistics, are given in Table 1.

3. Equation 2 tests robustness by replacing $\Delta^{2}$ (PRIME) in Equation 1 by $\Delta$ RPRIME. Equations 3 and 4 use a shorter sample, defined by particular regime breaks, to test for the parameter stability of Equation 1. 
Figure 1 : Gross and net domestic saving rates as a percentage of gross national disposable income

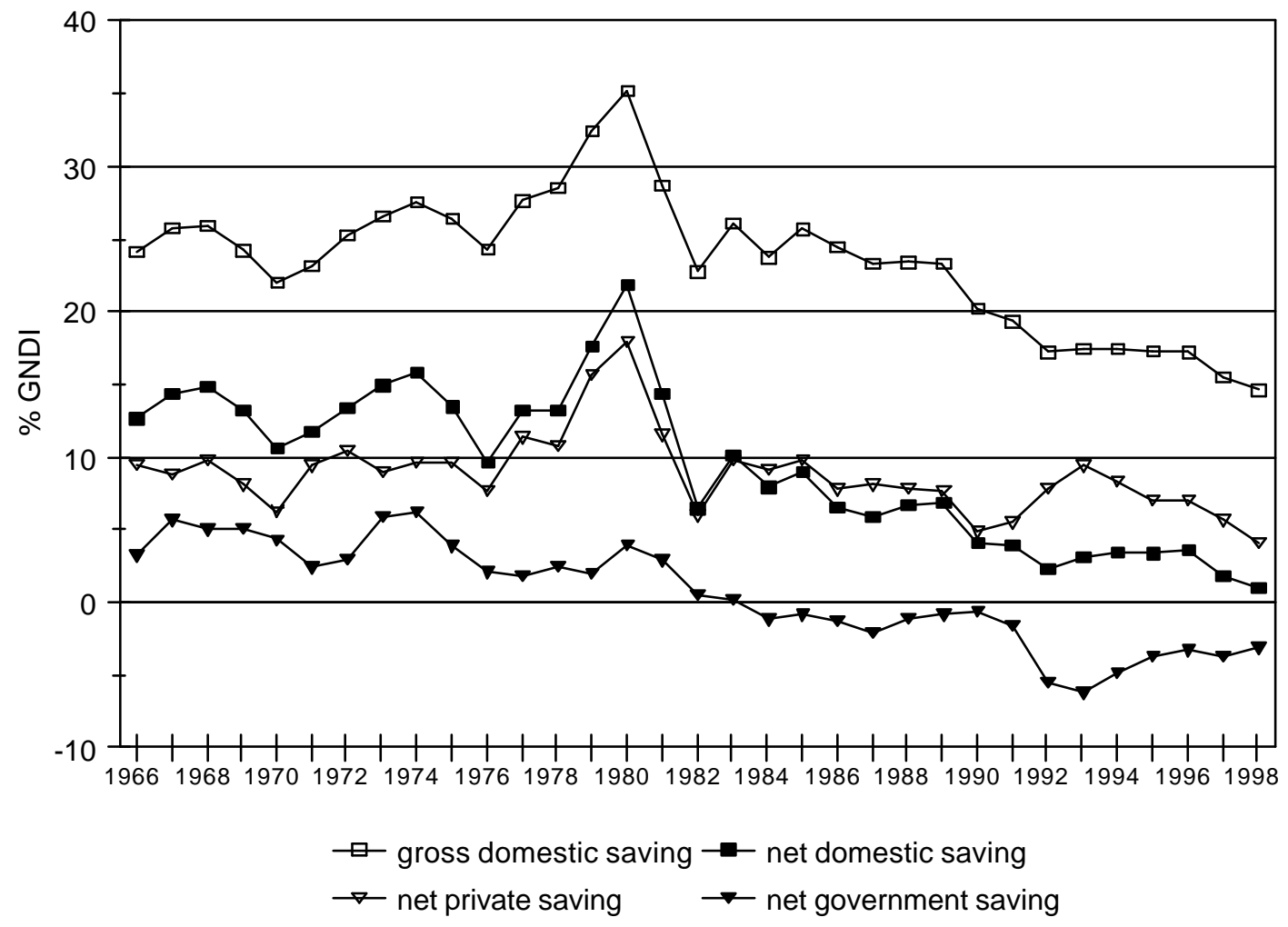


Figure 2: Real annual growth and the real prime interest rate

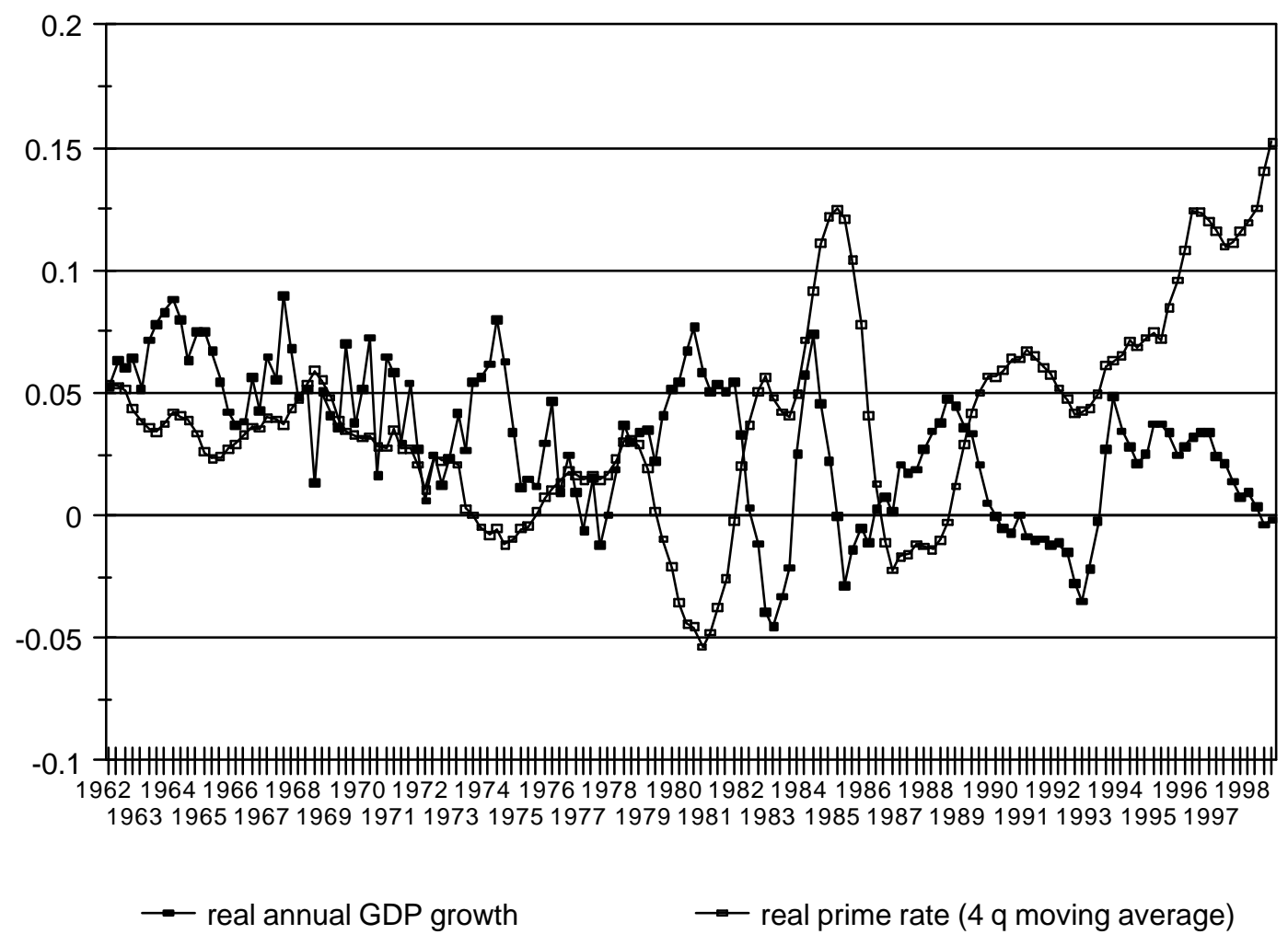


Figure 3 : The composition of net private saving (as a percentage of gross national disposable income)

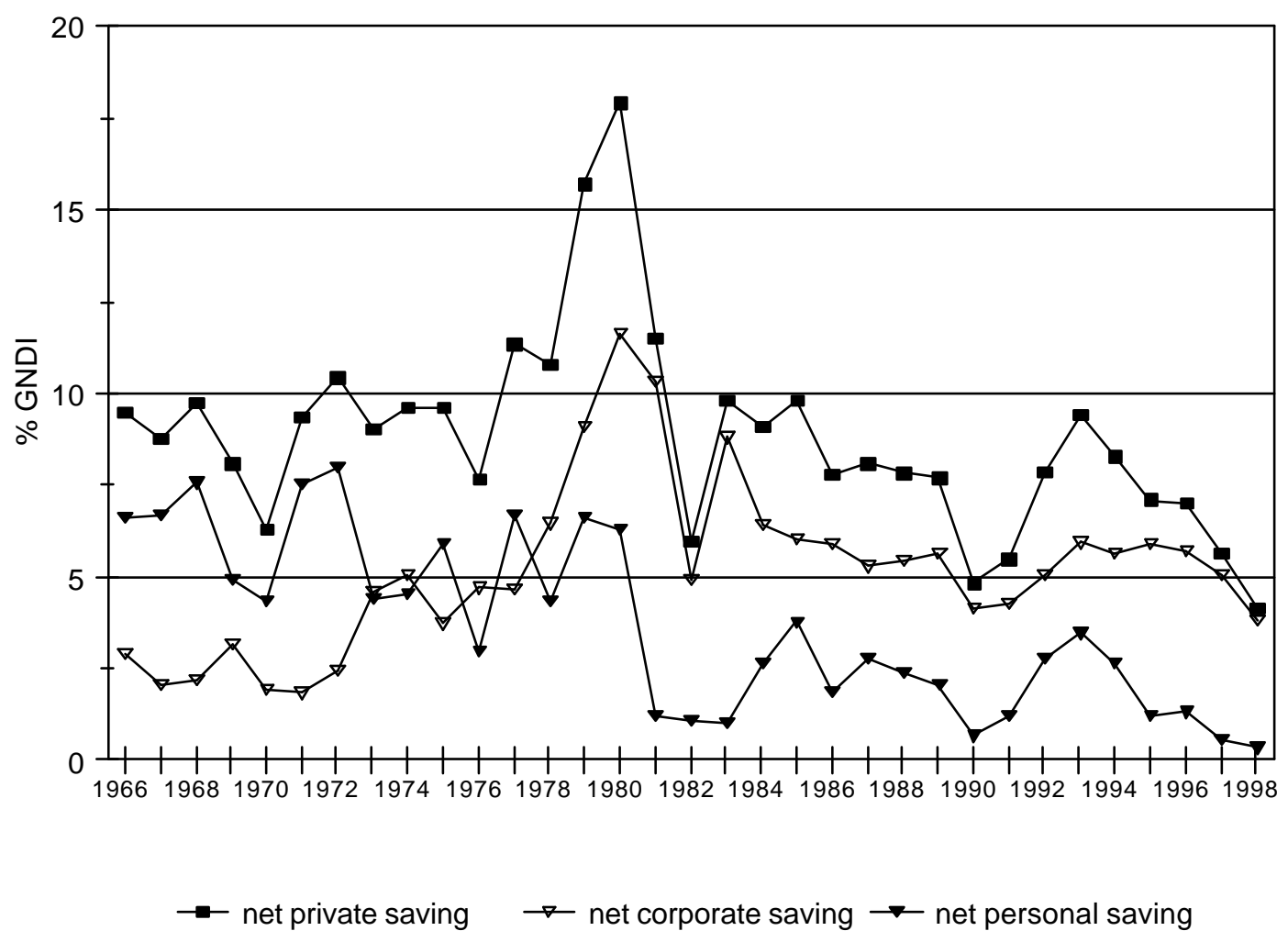


Figure 4 : Net personal saving relative to personal disposable and gross national disposable income

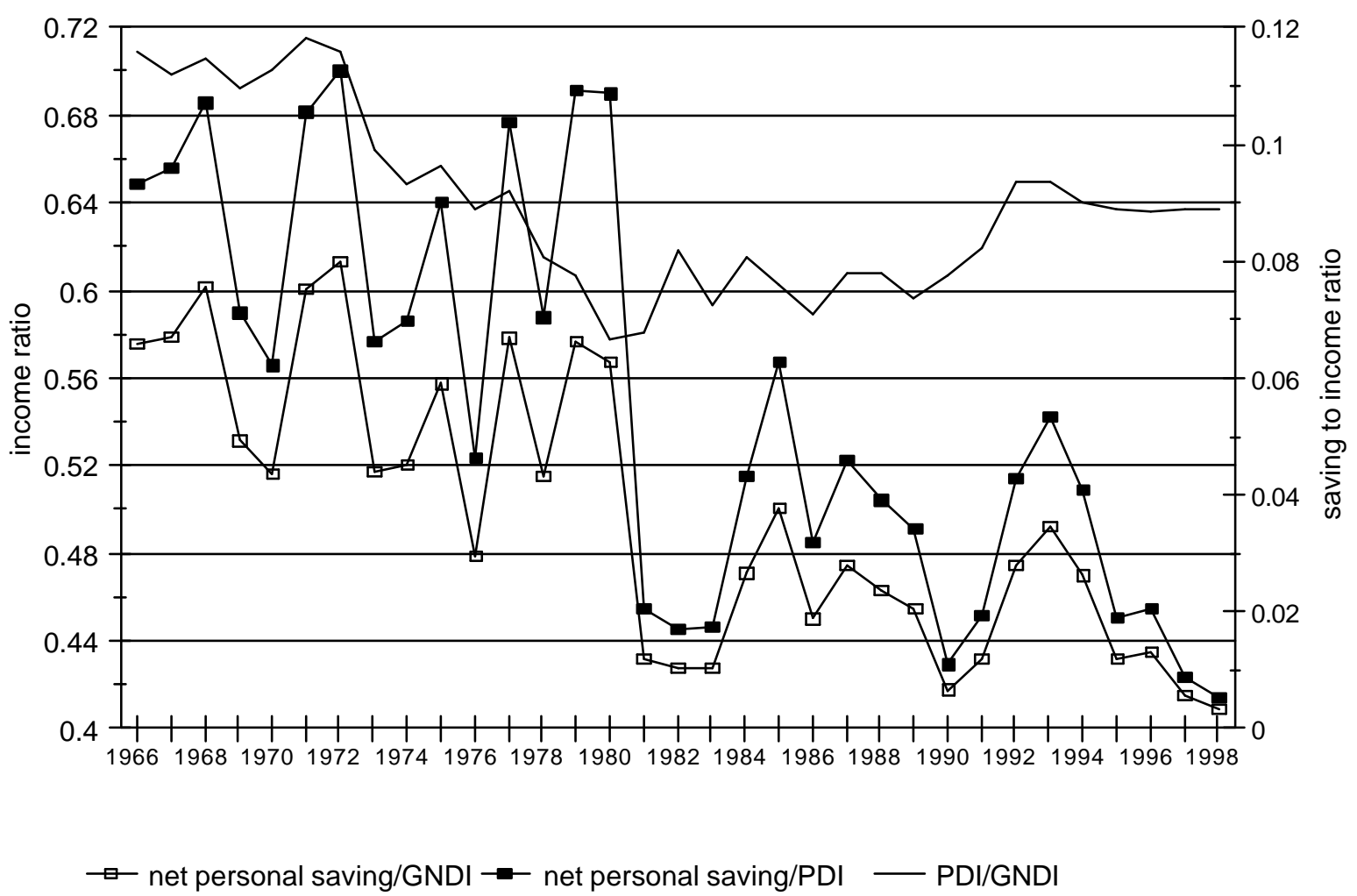


Figure 5 : Debt, liquid and illiquid assets relative to personal disposable non-property income

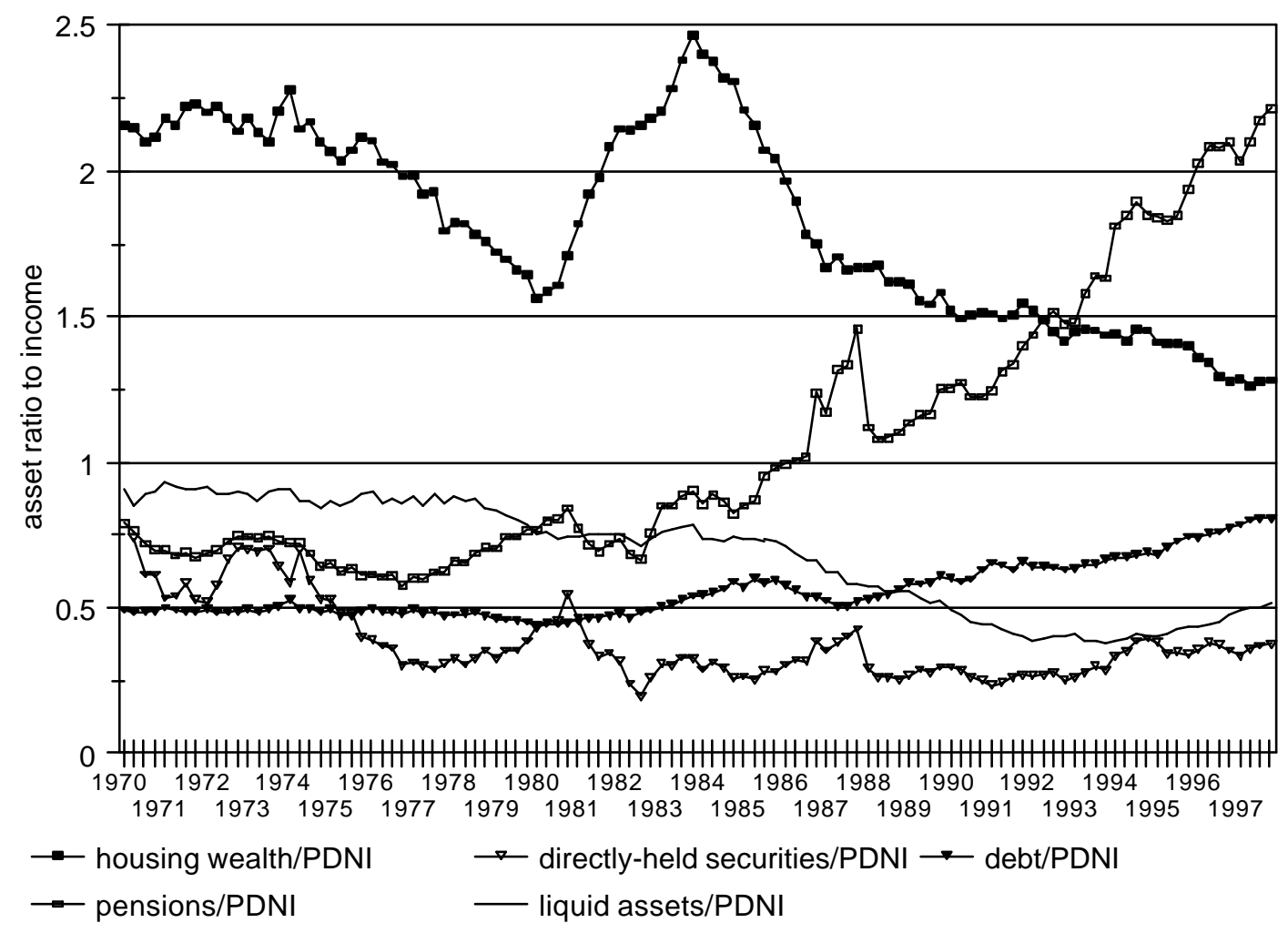


Figure 6 : Household debt to personal disposable non-property income and financial liberalisation

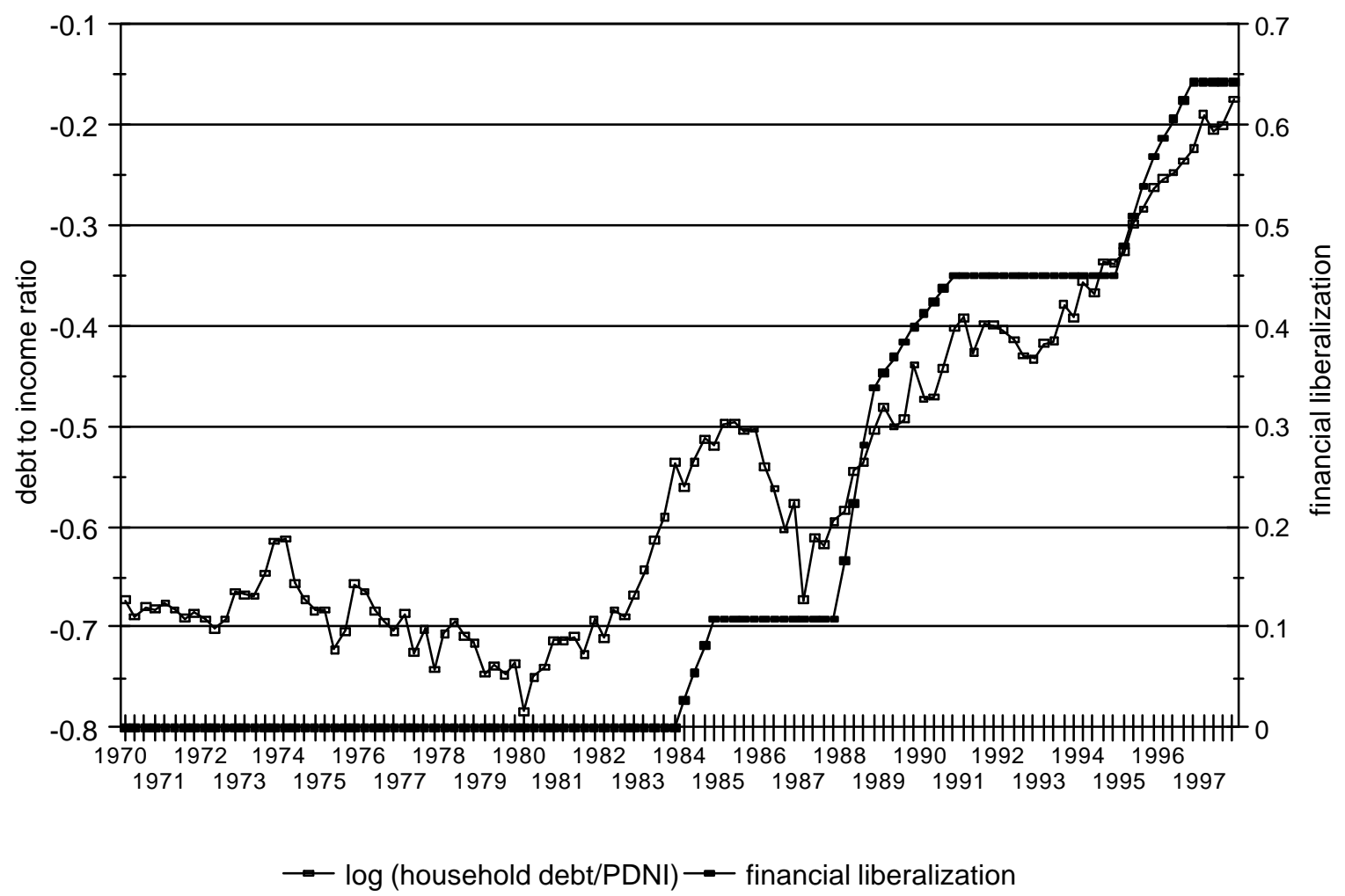


Figure 7 : Decomposition of the personal saving ratio into asset to income and relative income effects, financial liberalisation and real interest rate effects

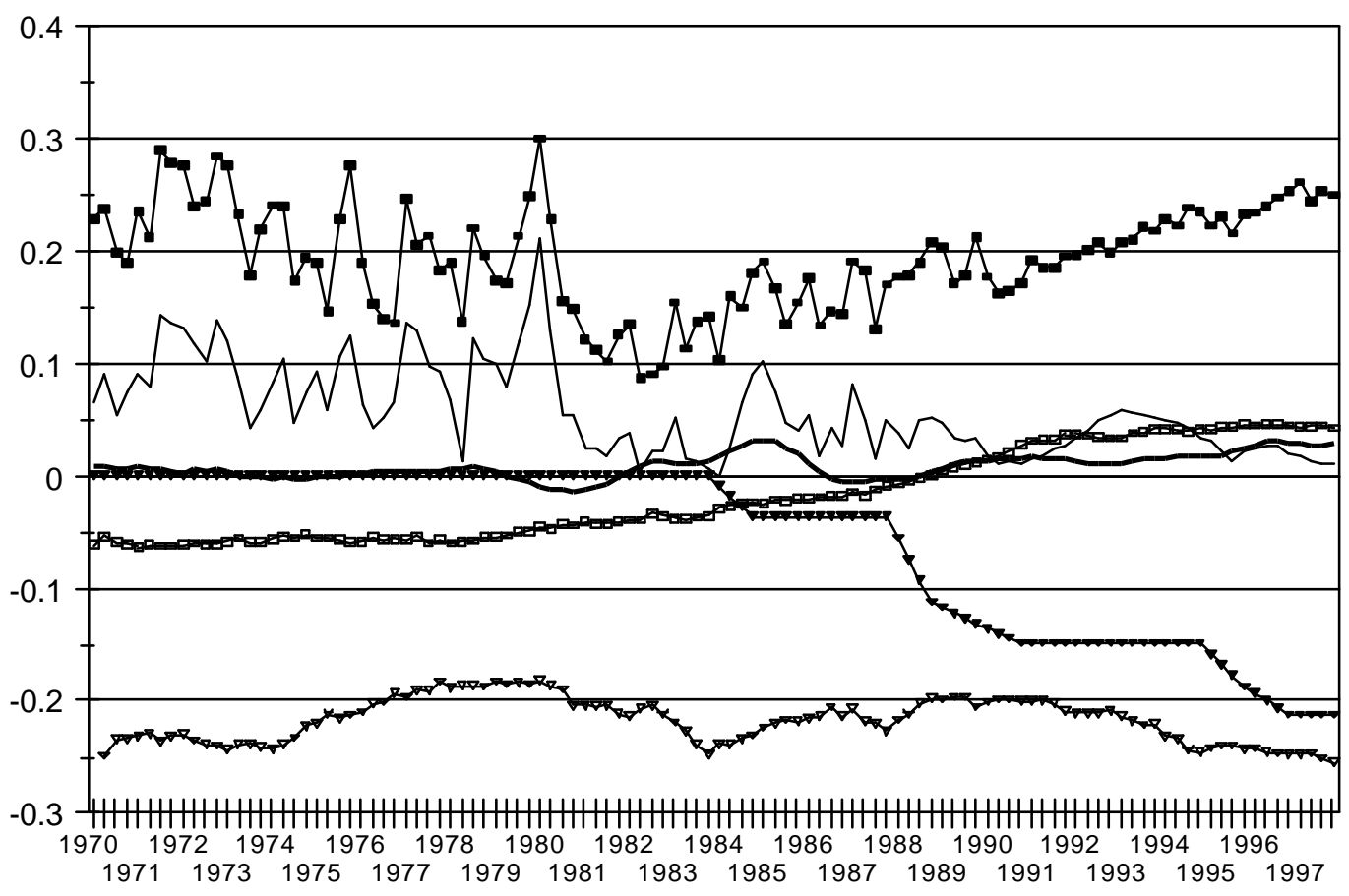

$\begin{array}{lll}\longrightarrow \text { personal saving/PDI } & \rightarrow \text { (liquid assets - debt)/PDNI } \rightarrow \text { composite illiquid assets/PDNI } \\ \rightarrow \log (\text { PDI/PDNI) } & \rightarrow \text { financial liberalization } & \text { real interest rate }\end{array}$ 
Figure 8 : The corporate saving rate, shares of net and gross profits in national income, and the ratio of net to gross profits

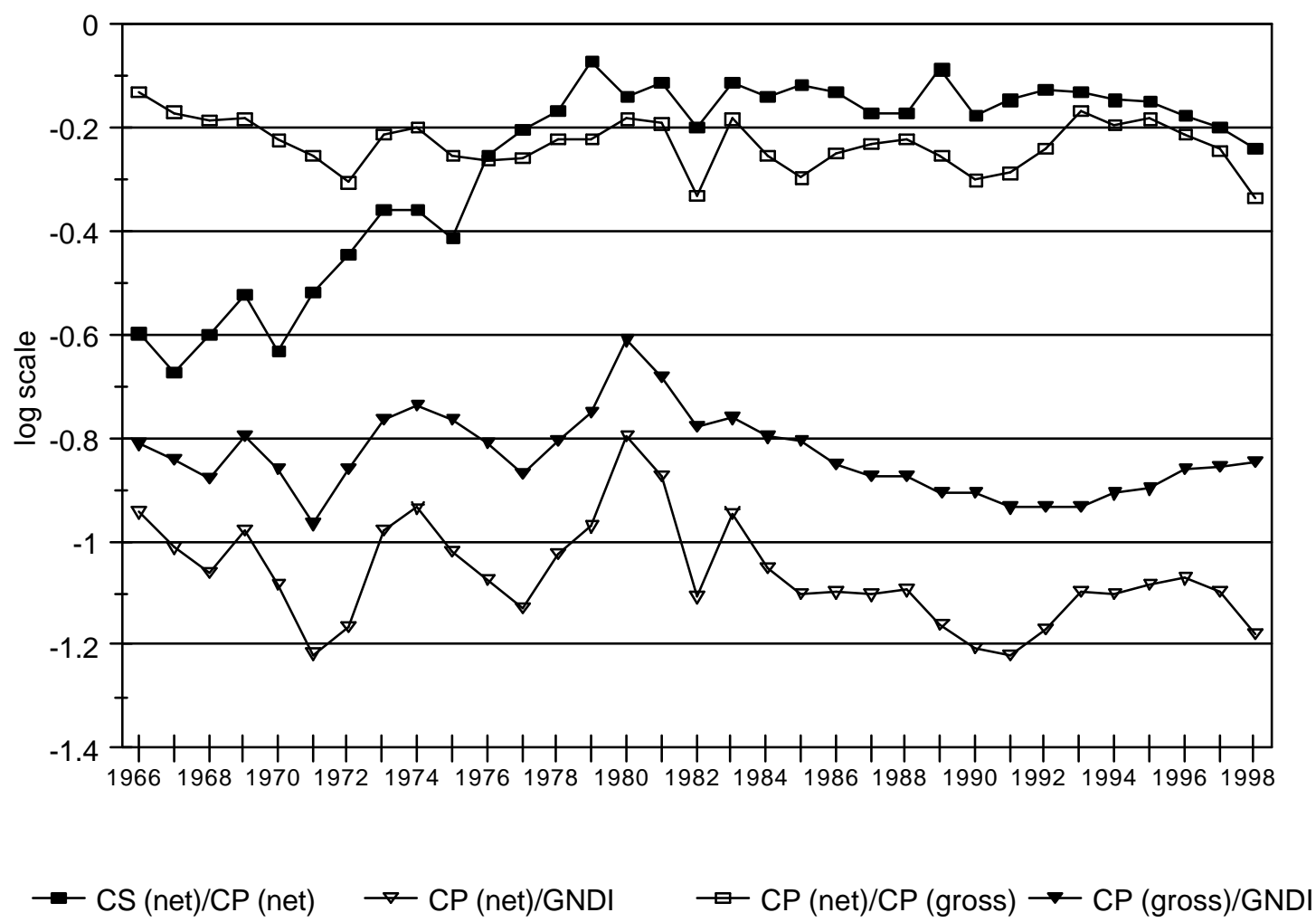


Figure 9 : Decomposition of the log ratio of corporate saving into (non-stationary) determinants multiplied by their regressions coefficients

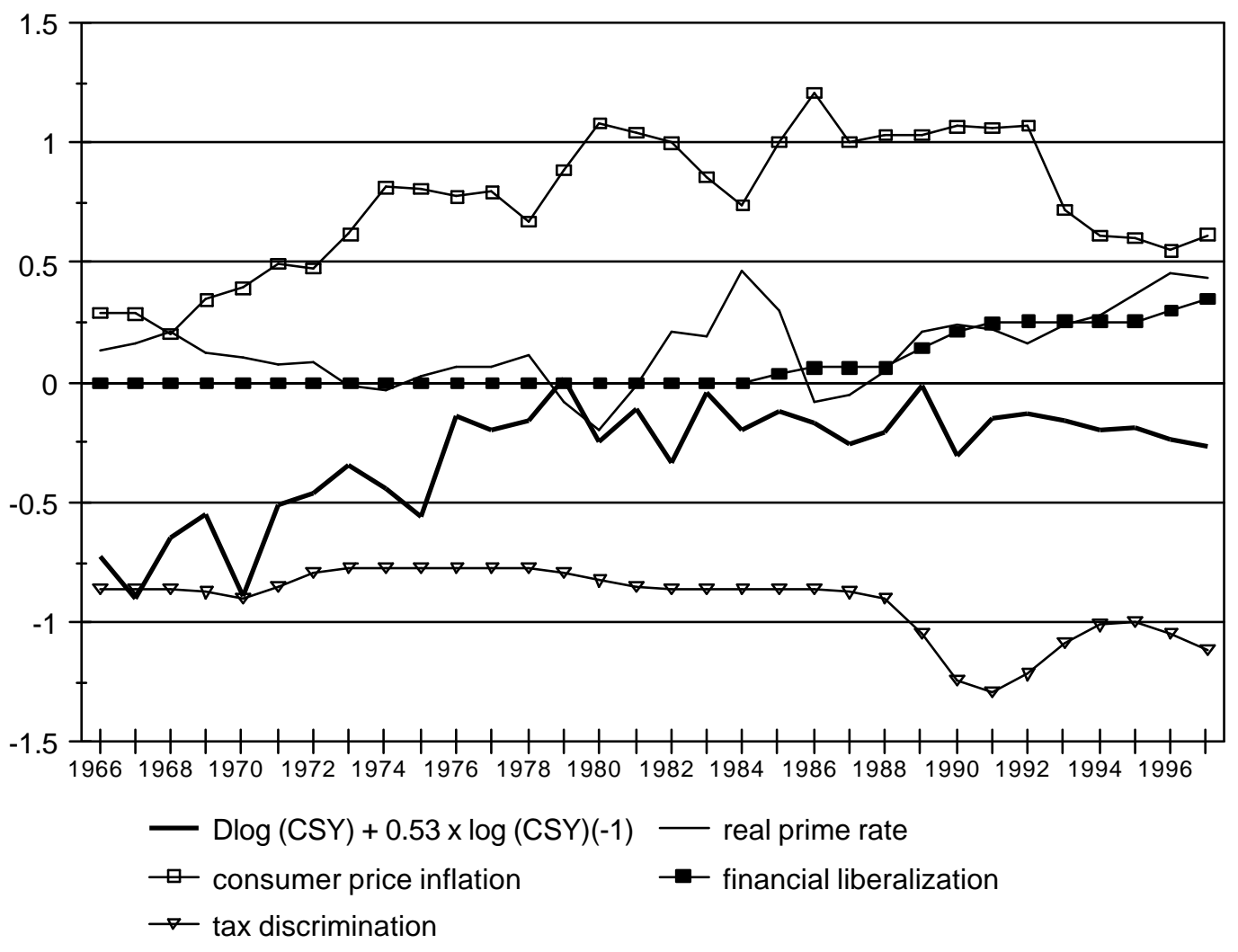


Figure 10: Decomposition of the log profit share into the main (non-stationary) determinants multiplied by their regressions coefficients

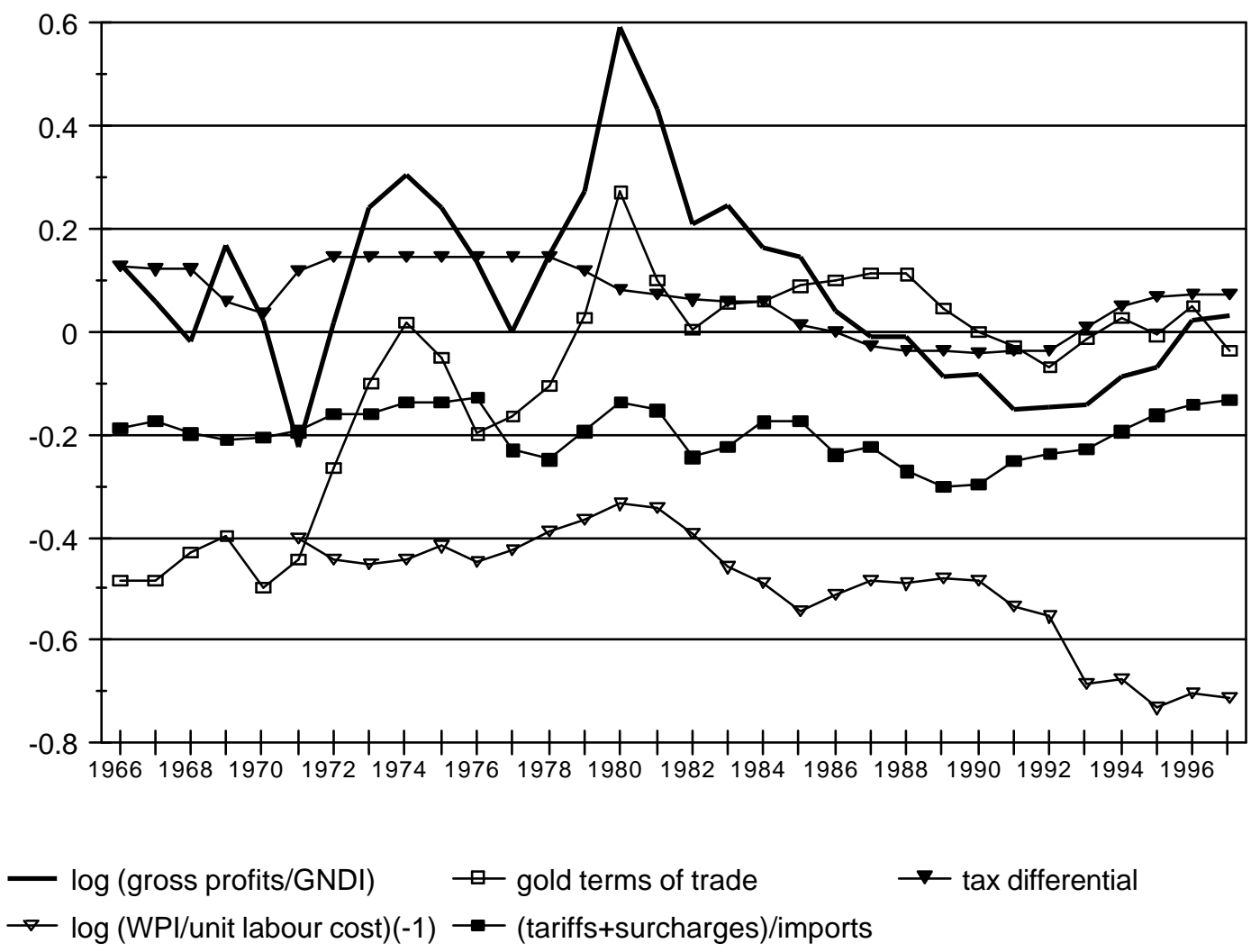

